\title{
Early and Middle Jurassic tectonically controlled deposition in the High-Tatric succession (Tatricum), Tatra Mountains, southern Poland: a review
}

\author{
Piotr ŁUCZYŃSKI ${ }^{1, *}$
}

1 University of Warsaw, Faculty of Geology, Żwirki i Wigury 93, 02-089 Warszawa, Poland

Łuczyński, P., 2021. Early and Middle Jurassic tectonically controlled deposition in the High-Tatric succession (Tatricum), Tatra Mountains, southern Poland: a review. Geological Quarterly, 65: 16, doi: 10.7306/gq.1583

The High-Tatric succession of the Tatra Mountains represents the Tatricum domain of the Central Western Carpathians, which in the Jurassic was located on the southern margin of the incipient and expanding Vahic Ocean - a branch of Western Tethys. This paper describes the various depositional consequences of extensional tectonic activity as it impacted on sedimentation in the High-Tatric succession of the Tatra Mountainsduring the Early and Middle Jurassic. Evidence of such impacts on depositional style and facies development are present within the Dudziniec, Smolegowa and Krupianka formations, in all the High-Tatric tectonic units. These impacts also include erosional surfaces and sedimentary gaps separating particular formations, commonly associated with minor angular unconformities. The Lower Jurassic, pre-Bajocian, Dudziniec Formation of the Kominy Tylkowe (autochthonous) Unit is developed in mixed carbonate-clastic facies. The occurrence and proportion of sand-dominated and carbonate-dominated facies, as well as their thickness differences, were controlled by syndepositional tilt-block tectonics, taking place both in depositional and in neighbouring source areas. The Smolegowa and Krupianka formations (Bajocian-Bathonian) occur in all High-Tatric tectonic units, but in the Czerwone Wierchy and Giewont units they are represented mainly by laterally discontinuous bodies of crinoidal limestone of very limited thickness. The preservation of these deposits only in some areas, as well as their thickness reductions, are effects of differentiated subsidence and uplift of isolated blocks taking place in an extensional regime. Moreover, the Krupianka Formation abounds in condensed facies with ferruginous crusts and stromatolites - a feature characteristic of rapidly drowning ocean margins. Deposits of the Dudziniec, Smolegowa and Krupianka formations are also preserved as infills of extensive systems of neptunian dykes penetrating mainly the Triassic substrate, which is yet another classic symptom of synsedimentary extension. The dominant influence of tectonics on sedimentary development ceased with the onset of deposition of the Raptawicka Turnia Formation in the Callovian.

Key words: Central Western Carpathians, Vahic Ocean, Jurassic, High-Tatric series, synsedimentary tectonics.

\section{INTRODUCTION}

During the Early and Middle Jurassic, the Tatricum palaeogeographical domain constituted a part of the Central Western Carpathian (CWC) block (e.g., Michalík, 1993, 1994; Jurewicz, 2005; Plašienka, 2012, 2018). Tatricum occupied the northern part of the block directly neighbouring a newly developing branch of the Western Tethys. In its Alpine sector this branch is referred to as the Piedmont-Ligurian Ocean (e.g., Lemoine et al., 1986; Dumont et al., 1996; Decarlis, et al., 2017), Alpine Tethys (e.g., Masini et al., 2013; Roda et al., 2019), AlpineMediterranean Tethys (e.g., Bernoulli and Jenkyns, 2009), and South Penninic Ocean (Frisch, 1979; McCann, 2008; Plašienka, 2012, 2018). In the Carpathian sector, terms such as: Pieniny Basin (e.g., Birkenmajer, 1986; Golonka and Krobicki, 2004); Vahic Ocean or Vahicum (e.g., Plašienka, 1995; Wieczorek, 2000, 2001; Jach and Reháková, 2019), Magura Ocean (e.g., Oszczypko et al., 2015) or the Pieniny

\footnotetext{
*E-mail: piotr.luczynski@uw.edu.pl
}

Received: November 13, 2020; accepted: February 4, 2021; first published online: XXXX, 2021
Klippen Basin (Lewandowski et al., 2005) are in use as local equivalents. In the present paper this oceanic basin is referred to as the Vahic Ocean (in a more narrow, Carpathian sense) or the Alpine-Mediterranean Tethys (in a broader, regional sense). Particularly important events, constituting turning points in the evolution of the southern passive margin of the Vahic Ocean, took place in the Jurassic and are registered in the sedimentary successions of the Tatricum domain (Dumont et al., 1996; Wieczorek, 2001).

In palaeogeographical reconstructions of the Jurassic Western Tethys realm, the Alpine-Mediterranean Tethys in its Vahic (Carpathian) sector is drawn as a narrow oceanic basin with passive margins separating the Central Carpathian Block from the European Platform (Fig. 1; Thierry and Barrier, 2000a, b), although Lewandowski, et al. (2005) presented arguments that it must have attained a substantial width. During that time, breakup and disintegration of extensive shallow areas occupied by carbonate and siliciclastic shelves took place. This resulted in the development of elongate and narrow basins, initially with a thinned continental crust and finally of an oceanic character (Bernoulli and Jenkyns, 2009), limited by normal faults and separated by elevated areas acting as pelagic swells and platforms or subaerially exposed land (Bernoulli and Jenkyns, 1974; Santantonio, 1994). The Vahic Ocean is one such prominent 


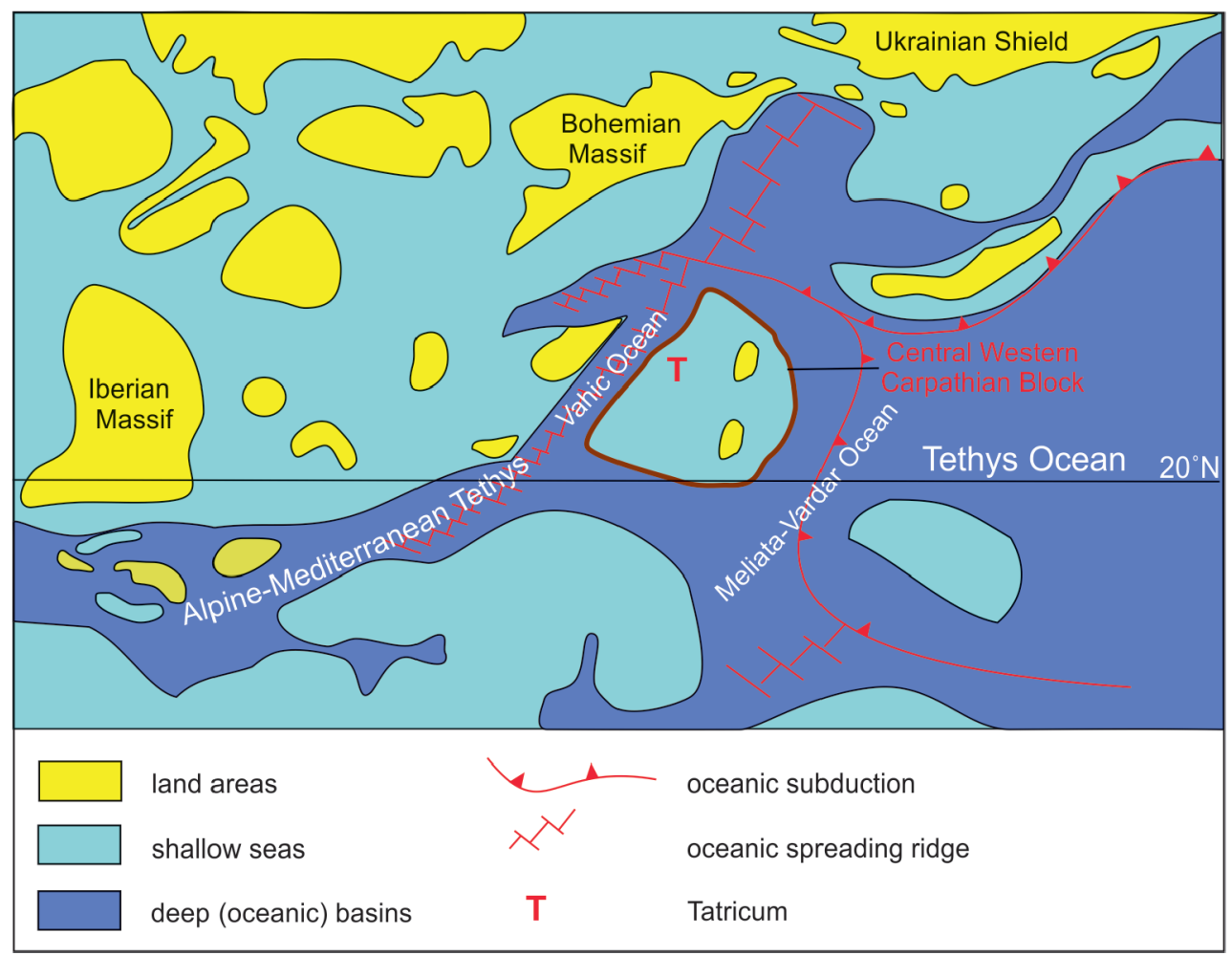

Fig. 1. Palaeogeographic map of the Carpathian part of the Tethyan realm at the Early/Middle Jurassic boundary (simplified after Thierry and Barrier, 2000a, b)

basin (Plašienka, 2018). Its history is often divided into a number of phases (Wieczorek, 1989; Plašienka, 1995, 2012; Plašienka and Soták, 2015) representing different stages of oceanic development - pre-rift (Permian to Triassic), syn-rift (Jurassic) and post-rift or syn-orogenic (Cretaceous to Paleogene). Three main rifting phases are recognized in the Jurassic of the Western Carpathians: the Zliechov, Devin and Krasin phases (Plašienka, 2003; Froizheim et al., 2008).

Several general reconstructions of the palaeoposition of the Central Western Carpathians and adjacent areas, and of their relation to the Alps, have been presented, based on compilations of large amounts of regional data (e.g., Plašienka et al., 1997; Kozur and Mock, 1997; Csontos and Vörös, 2004; Golonka and Krobicki, 2004; Froitzheim et al., 2008). However, as noted by Plašienka (2018), local sedimentary phenomena, preserved only in particular local successions, can shed much light on large-scale geotectonic and orogenic processes. This paper describes such data from the Jurassic successions representing the Tatricum domain in the High Tatra Mountains. It summarizes data, ideas and reconstructions concerning the influence of tectonic phenomena on deposition in the High-Tatric succession during the Early and Middle Jurassic. Apart from facies analysis, particular attention was paid to phenomena such as stratigraphic gaps and unconformity surfaces, neptunian dykes, condensed horizons and terrigenous admixtures in carbonate facies. All these data are discussed in terms of differences in the development and completeness of the Lower and Middle Jurassic succession within the Tatricum of the Tatra Mountains (i.e. differences between particular tectonic units), as well as in terms of comparison with neighbouring domains.

\section{REGIONAL GEOLOGICAL SETTING}

In the Jurassic, the Central Western Carpathian block was located between the incipient and expanding Vahic Ocean in the north (north-west) and the main Meliata-Vardar branch of the Tethys Ocean in the south (south-east). It constituted a relatively elevated area that was surrounded by deeper basins (Fig. 1; Thierry and Barrier, 2000a, b). The block became partly emergent during some intervals of the Jurassic, but mainly it was a place a of a diverse carbonate and clastic marine deposition (Uchman, 2014a). The main palaeogeographical units representing various parts of the Central Carpathian area are the Tatricum, Fatricum and Hronicum tectono-facies domains (Andrusov et al., 1973; Kotański, 1979). The Tatricum domain occupied the northernmost part of the Central Carpathian block, directly neighbouring the Vahic Ocean to the north. Directly south of Tatricum was the Fatricum domain, generally representing the central part of the block, and farther south the Hronicum domain, which sloped towards the main branch of the Jurassic Tethys - the Meliata-Vardar Ocean.

Each tectono-facies domain is characterized by its own sedimentary succession and its deposits are today exposed in a number of areas belonging to separate tectonic units - Tatric, Fatric and Hronic. All three units are present in the Tatra Mountains, as well as in several other core massifs of the Central Western Carpathians (Kotański, 1979; Vozár and Káčer, 1996). The deposits of the Tatric Unit are present on the slopes of the Malé Karpaty, Považský Inovec, Malá Fatra, Vel'ká Fatrá, Nízke Tatry and other mountains areas, forming their sedimentary cover. This cover (in the Tatra Mountains and elsewhere) is of- 


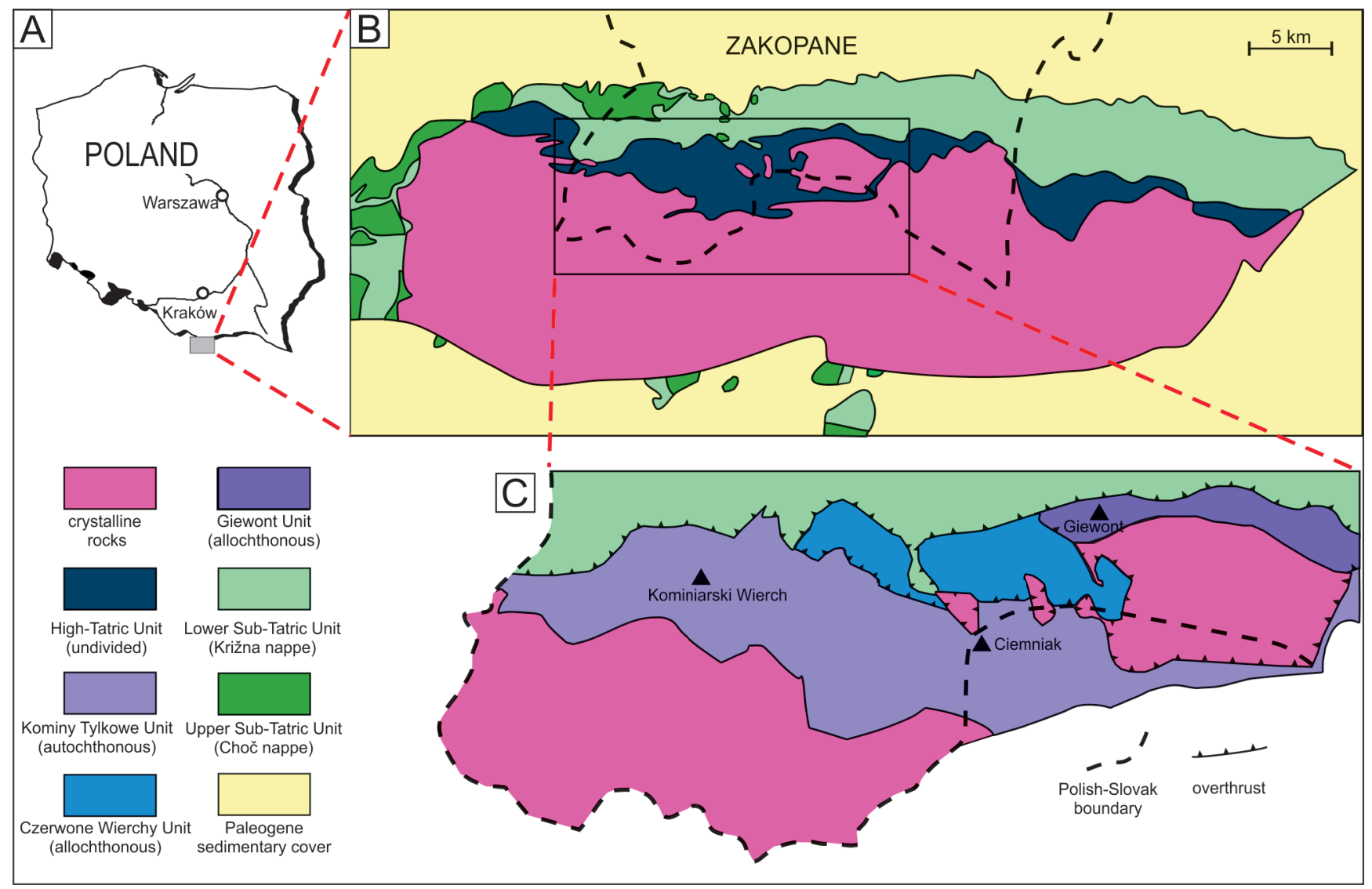

Fig. 2. Structural map of the Tatra Massif

A - geographic location of the Tatra Mountains; B - main tectonic units of the Tatra Massif; C - structural division of the High-Tatric Unit in the Polish sector of the Western Tatra Mountains (after Bac-Moszaszwili et al., 1979, simplified)

ten traditionally divided into autochthonous and allochthonous units (e.g., Kotański, 1979; Łuczyński, 2002; Uchman, 2014a). In the autochthonous units, the sedimentary cover is usually in direct contact with its crystalline basement, whereas the allochthonous units are developed as nappes tectonically transported from the south. The term "autochthonous", however, has to be treated only in terms of the relation of the sedimentary cover to its direct crystalline basement and not in a palaeogeographic sense, as the crystalline rocks of the Central Western Carpathians are also incorporated into tectonically transported units (e.g., Michalík, 1994).

In the Tatra Mountains, which are the northernmost core massif of the Central Western Carpathians, located on the Polish-Slovak boundary (Fig. 2A), the Permo-Mesozoic sedimentary cover is preserved on the northern slopes of the massif (Fig. 2B). Traditionally it is divided into the High-Tatric and Sub-Tatric successions or series (Kotański, 1959a, 1961; Rabowski, 1959; Lefeld et al., 1985). The Sub-Tatric succession, exposed in the lower parts of the mountains, is represented by two tectonic units (nappes) corresponding to two of the CWC tectono-facies domains: the Križna nappe (Lower Sub-Tatric) representing Fatricum, and the Choč nappe (Upper Sub-Tatric) representing Hronicum. Previously a third Sub-Tatric Unit, the Strážov nappe, was distinguished in the Tatra Mountains (e.g., Kotański, 1973), but later this term was abandoned and its deposits were incorporated into the Choč Unit (Michalík and Gaździcki, 1980; Iwanow and Wieczorek, 1987). The Tatricum tectono-facies domain is represented by the High-Tatric succession, which is preserved in both autochthonous and allochthonous positions in relation to the crystalline basement.
The High-Tatric succession belongs to three main tectonic units (Fig. 2C): the autochthonous Kominy Tylkowe Unit, and the allochthonous Giewont and Czerwone Wierchy units (or nappes). Exposures of Jurassic rocks occur in all three units, forming three roughly parallel latitudinal bands (Fig. 3). The Kominy Tylkowe Unit is further divided into the autochthonous unit sensu stricto, with the sedimentary rocks being undetached and lying in their original position in relation to the crystalline core of the Tatra Mountains, and parautochthonous units, in which the sedimentary rocks were detached, but probably moved only on minor distances (e.g., the Rzędy pod Ciemniakiem area; Fig. 3A). The allochthonous units are detached from their basement and overthrust northwards (e.g., Jurewicz, 2012), with the Giewont Unit undergoing the longest transport and thus palaeogeographically representing areas located farthest to the south.

In the Tatra Mountains (Fig. 4), the Jurassic deposits of the High-Tatric succession (Lefeld et al., 1985) are represented by four formations: Dudziniec, Smolegowa, Krupianka and Raptawicka Turnia. The occurrence, development and thickness of particular formations varies between particular units of the High-Tatric succession (Łuczyński, 2002). Some of the units (including the Smolegowa and the Krupianka formations, together forming the Dunajec Group) were incorporated into the lithostratigraphic division of the Tatra Mountains in the scheme earlier proposed for the Pieniny Klippen Belt (Birkenmajer, 1977), which has had controversial consequences (Wieczorek, 1988; Łuczyński, 2000). 


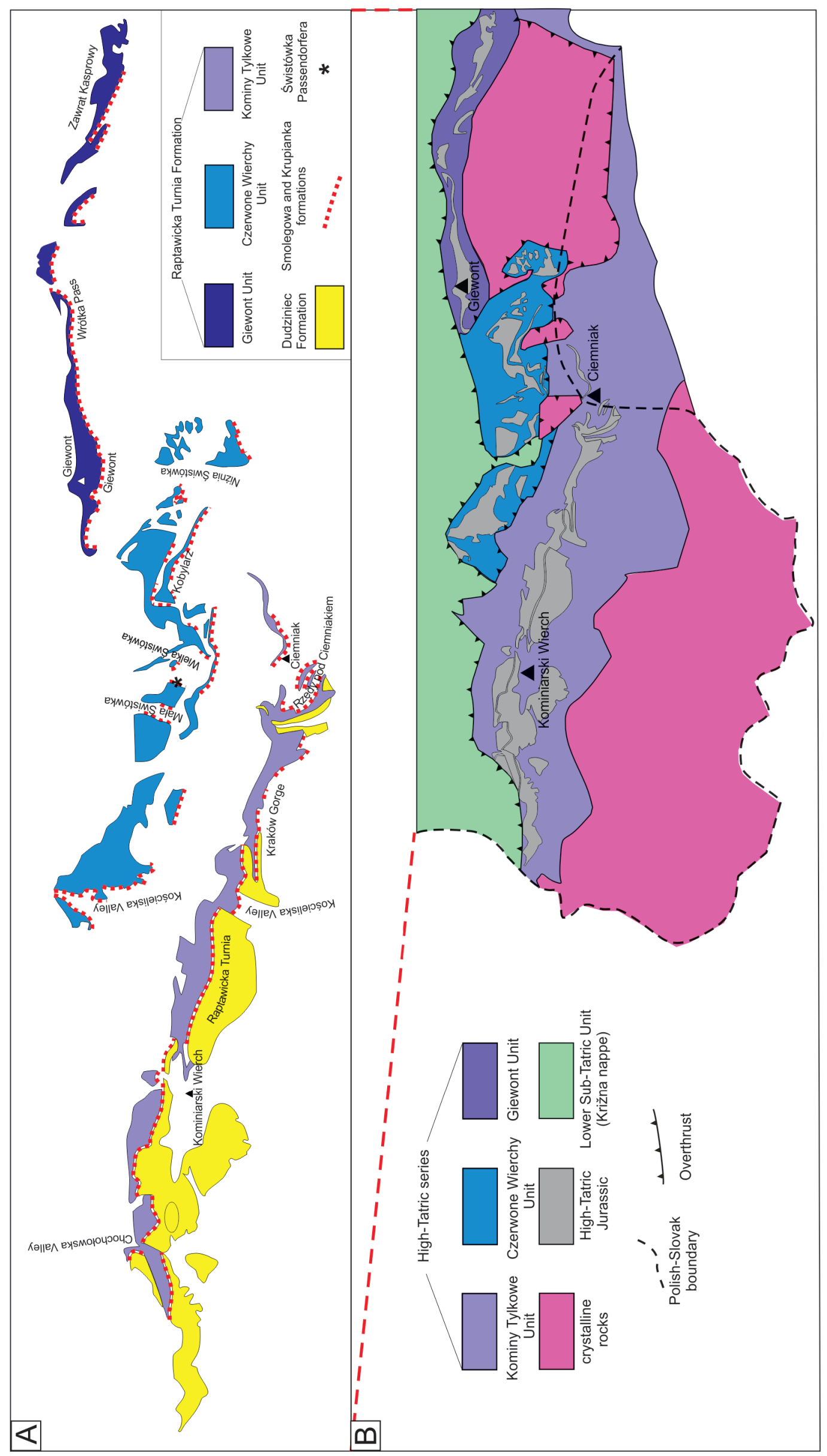

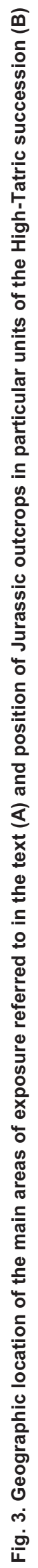



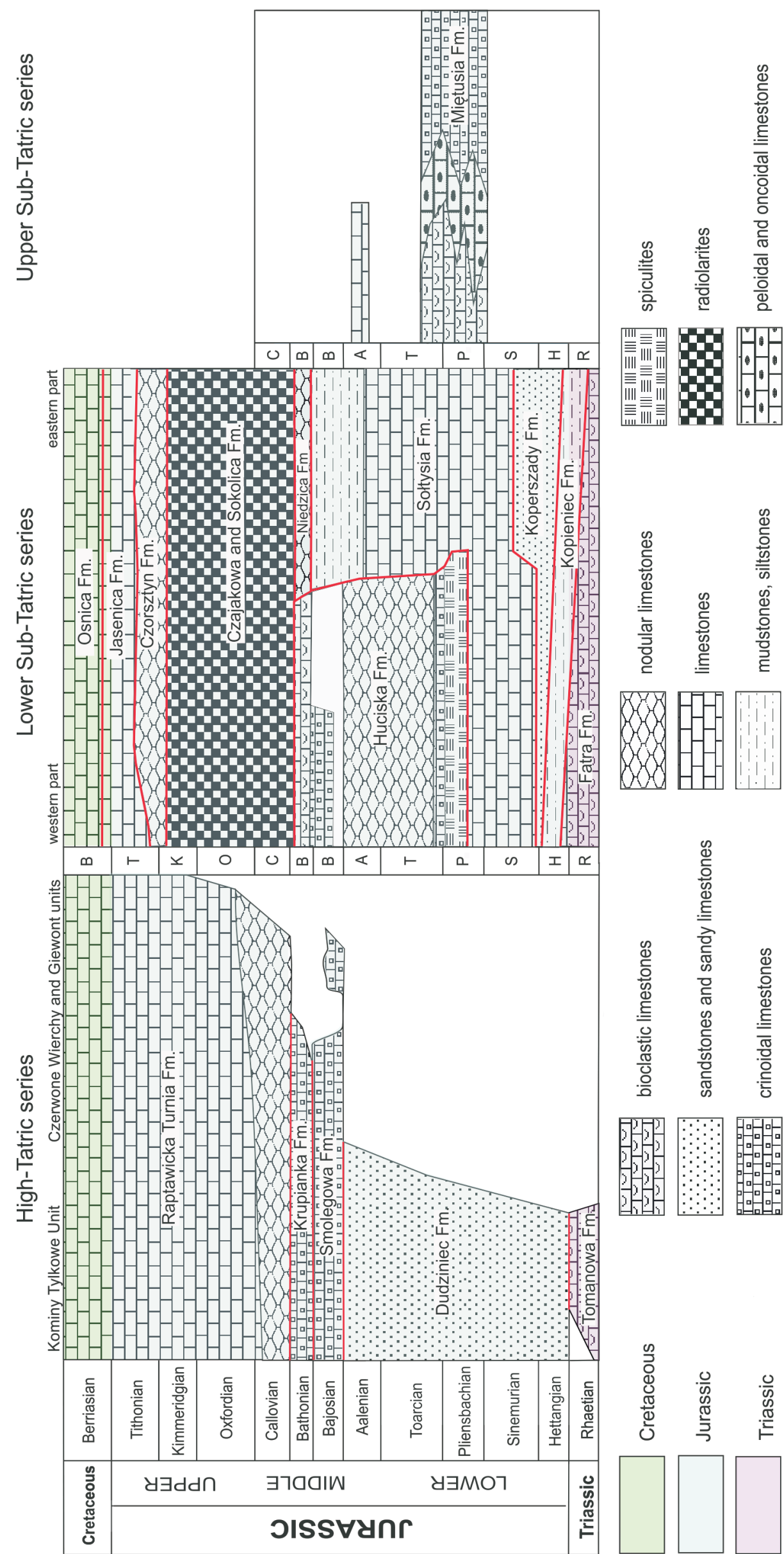

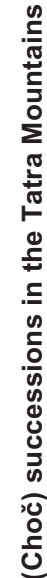

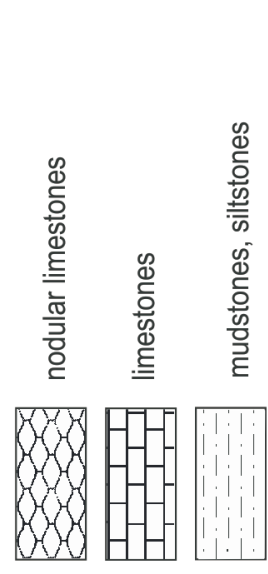

草 


\section{INFLUENCE OF SYNDEPOSITIONAL TECTONICS ON THE DEVELOPMENT OF THE HIGH-TATRIC LOWER AND MIDDLE JURASSIC}

Early and Middle Jurassic deposition in the Tatricum domain took place under the strong influence of synsedimentary tectonics. An extensional regime, connected mainly with rifting in the neighbouring opening Vahic Ocean, prevailed during the whole Jurassic (e.g., Plašienka, 1995, 2012, 2018; Jurewicz, 2005). The impact of this regime is variously registered throughout all the sedimentary successions of the High-Tatric succession; however, it included distinct culminations, considered as turning points in the area's sedimentary development (e.g., Dumont et al., 1996; Wieczorek, 2000, 2001; Plašienka, 2003). The influence of syndepositional extensional tectonics is variously demonstrated and reflected in different parts of the High-Tatric Unit. Internal differentiation of the unit in terms of completeness of the sedimentary succession has long been recognized. Kotański (1961) distinguished a number of High-Tatric sedimentary units, based mainly on the character of the Triassic/Jurassic contact and thickness differences.

The picture provided, due to imprecise stratigraphical data and because of the scattered exposures, inevitably suffers from correlation problems, both between particular sections and with other Carpathian palaeogeographic regions. The extensional tectonic regime governed facies development during the Jurassic also in areas adjacent to the Central Carpathian Block, such as the Fatricum domain, represented by the Lower Sub-Tatric (Krížna) succession (e.g., Jach, 2005; Jach et al., 2012, 2014, 2017, 2019; Jach and Reháková, 2019), and the Hronicum domain represented by the Upper Sub-Tatric Choč succession (e.g., Uchman, 1993, 2014b).

The symptoms and effects of tectonic impacts on Jurassic sedimentation in the High-Tatric Unit are recorded through:

- facies development and distribution, and particularly the occurrence and pattern of high-energy deposits;

- the quantity, character and composition of clastic terrigenous admixtures in the carbonate deposits;

- thickness differences of particular stratigraphic units and lithofacies;

- stratigraphic gaps and stratigraphically condensed horizons;

- variously developed unconformity surfaces;

- the occurrence, distribution and developmental history of neptunian dykes.

All these aspects are discussed in terms of their internal variability within the Tatricum domain of the Tatra Mountains and as regards differences between particular tectonic units. Where sufficient availability of data permits, the emerging picture is also compared with the Jurassic of neighbouring domains.

\section{TRIASSIC/JURASSIC TRANSITION}

In the Tatra Mountains, the Triassic/Jurassic transition is marked by distinct differences between the sedimentary successions of the High-Tatric and Sub-Tatric successions. During most of the Triassic, deposition followed roughly the same course in the Tatricum and Fatricum domains of the Tatra Mountains (see e.g., Uchman, 2014a), whereas towards its end, in the Rhaetian, this picture started to change. From this point on, and through most of the Jurassic, Tatricum represented the generally more shallow part of the Central Carpathian area as compared with Fatricum and Hronicum.
This differentiation coincided with the onset of the syn-rift stage of development of the Vahic Ocean (e.g., Wieczorek, 1989; Plašienka, 1995, 2012; Feinst-Burkhardt et al., 2008; Plašienka and Soták, 2015).

The latest Triassic (Rhaetian) is represented by the Tomanowa Formation in the High-Tatric succession and by the Fatra Formation in the Lower Sub-Tatric succession (Fig. 4; Uchman, 2014a). The Fatra Formation is developed mainly as shallow water fossiliferous limestones and marly shales deposited near to elevated land areas (Michalík et al., 2007, 2013; Gaździcki, 2014a). Sedimentation in the Fatricum domain (Zliechov Basin) was continuous in marine facies across the Triassic/Jurassic boundary (Gaździcki, 1983). The High-Tatric Tomanowa Formation is in turn developed mainly as sandstones and mudstones with some intercalations of organogenic and oolitic limestone with abundant plant remains and terrigenous material (Radwański, 1968; Michalík et al., 1988; Jaglarz et al., 2014). Deposition in the Tatricum domain took place in a morphologically diverse land area, which was periodically subject to minor marine transressions (Michalík, 1980).

Both the differences in depositional style between Tatricum and Fatricum, and the topographic diversity within Tatricum, were tectonically induced and associated with the beginning of rifting in the Carpathian section of the Alpine-Mediterranean Tethys (see e.g., Michalík, 1993, 1994). After Rhaetian transgression in the Zliechov Basin (Fatricum), which is recorded in the facies development of the Fatra Formation, the Tatricum domain started to function as a relatively elevated area surrounded by deeper basins (Fig. 5) to both south (Zliechov Basin) and north (Pieniny Basin). In the Sub-Tatric succession, deposition was generally continuous across the Triassic/Jurassic boundary (Michalík et al., 2007, 2013), and the Fatra Formation is overlain by the Lower Jurassic Kopieniec Formation ("Gresten Beds") developed mainly as shales and quarzitic sandstones, with a diachronous lower boundary (Gaździcki, 1975, 2014b; Gaździcki and Iwanow, 1976).

Following deposition of the Tomanowa Formation, those parts of the Tatricum domain in the Tatra Mountains represented by the allochthonous units were elevated and eroded, which resulted in the occurrence of a major stratigraphic gap in the Czerwone Wierchy and Giewont units, embracing the entire Upper Triassic and Lower Jurassic. It is impossible to tell the precise timespan during which the erosion of the Triassic sequences took place, and thus to determine whether deposition of the Rhaetian (and parts of the Lower Jurassic) was indeed limited only to the autochthonous unit. It is generally agreed that the main phase of subaerial erosion took place in the latest Triassic, and was followed by episodes of marine erosion in the Early Jurassic (Uchman, 2014a). A break in deposition and uplift of the allochthonous succession already in the Rhaetian is indicated by the lack of uppermost Triassic clasts in the terrigenous admixture within the Middle Jurassic deposits, which in this area rest with a stratigraphic gap on the Triassic (Łuczyński, 1999; Jezierska and Łuczyński, 2016).

The erosion of the Triassic sequences reached different stratigraphical levels in particular sections, indicating tilting of the eroded blocks. This is most evident in the Kominy Tylkowe Unit, in which the Lower Jurassic Dudziniec Formation rests on various parts of the Triassic succession (Kotański, 1959a, b; Bac-Moszaszwili et al., 1979; Dumont et al., 1996). The succession is continuous across the Triassic/Jurassic boundary probably only in the Chochołowska Valley region (Fig. 3; Radwański, 1968; Wójcik, 1981). The differences in sedimentary development between the autochthonous Kominy Tylkowe Unit, with deposition of the Rhaetian Tomanowa Formation, and the prob- 
Time of deposition of the Dudziniec Formation
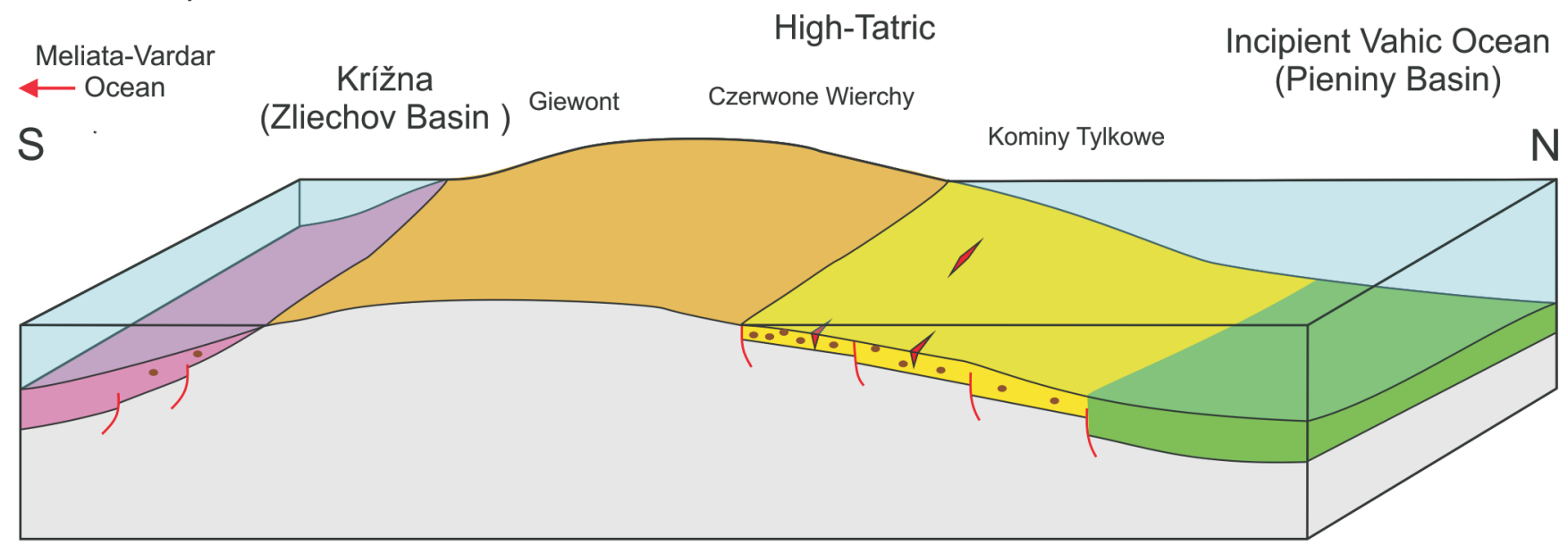

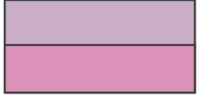

Zliechov Basin

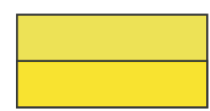

High-Tatric Basin

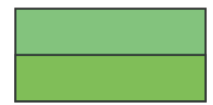

Pieniny Basin

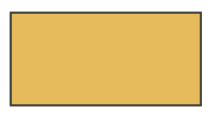

elevated area
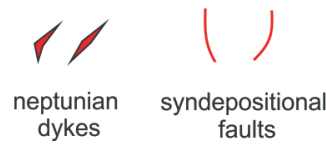

$\because \bullet$

dykes faults

Fig. 5. High-Tatric domain and the surrounding areas during the deposition of the Dudziniec Formation (Early Jurassic to Aalenian?)

ably uplifted and eroded allochthonous Czerwone Wierchy and Giewont units, marks the beginning of a new palaeogeographic situation within the Tatricum domain, which prevailed during most of the Jurassic. The allochthonous units, palaeogeographically representing areas located on the southern side of the domain, began to function as an isolated uplifted block (or a number of blocks) surrounded by deeper areas to the north and south (Fig. 5).

In the Smytnia Valley, being an extension of the Kościeliska Valley (Fig. 3), the top of the Norian limestones, which are the youngest Triassic deposits in the section, is corroded and abraded, and a palaeocliff structure with large boulders at its foot is preserved (Radwański, 1959a). The Norian is overlain by the Lower Jurassic carbonate-clastic Dudziniec Formation, which indicates emergence of the area, followed by a subsequent transgression (Radwański, 1959b). The boulders are covered by borings of the polychaete Potamilla, within which Rhaetian sediments are preserved (Radwański, 1959a). This indicates that deposition of the Rhaetian Tomanowa Formation probably took place at least across most of the autochthonous unit, including the Kościeliska Valley region. In Smytnia, the whole Rhaetian ( 65 m) has been removed (Kotański, 1959a, b; Radwański, 1968), and the thickness of the Norian has been reduced from $\sim 130$ to $30 \mathrm{~m}$ (Radwański, 1959a). Erosion of the Norian limestones is indicated by the lack of Potamilla borings on the tops of the layers, and their limitation only to boulders. The Kopieniec Starorobociański and Bobrowiec sections in the Chochołowska Valley, with continuous marine deposition at that time, are located at a distance of just $4-5 \mathrm{~km}$ from the Smytnia Valley, and this relation has not changed markedly since the Triassic. This shows the magnitude of the uplift of the Kościeliska Valley region in the east in relation to the Chochołowska Valley region in the west, due to syndepositional faulting (at least more than $100 \mathrm{~m}$ ). Such faulting activity, and the similar general relation of the two regions, prevailed through the Early Jurassic.
The top of the Norian limestones in the Smytnia Valley, close to the cliff structures, is cut by clastic dykes and veins filled by Early Jurassic material (Radwański, 1959a). The development of the voids took place after the deposition of the Rhaetian shales (absent from the voids) and after lithification of the host Norian limestones, but prior to the deposition of the Dudziniec Formation. This was the first of many episodes of the development of sedimentary dykes in the High-Tatric succession during the Jurassic (Łuczyński, 2001a; Łuczyński and Jezierska, 2018). The dykes cutting the Norian are filled mainly by sandy limestones and sandstones identical to the overlying deposits. However in some places, particularly in their more remote parts, the dykes are filled by fine dolomitic marls. The formation of such infills may result from a sieve effect in the veins, although Radwański (1959a) interpreted them as alluvial residues of dissolved Norian host rocks, transported in suspension and reprecipitated within the voids. Dissolution of subaerially exposed carbonate sequences might have taken place directly in the vicinity of the dykes within the autochthonous unit, but also could have occurred in the uplifted allochthonous units, the dissolved material being washed down to the Kominy Tylkowe Unit area of marine deposition.

\section{TIME OF DEPOSITION OF THE DUDZINIEC FORMATION (HETTANGIAN-AALENIAN)}

The Dudziniec Formation occurs only in the Kominy Tylkowe Unit, in which it rests on various Triassic strata, predominantly the Rhaetian (Rabowski, 1959; Kotański, 1959a; Radwański, 1959a; Dumont et al., 1996). It is developed in mixed sandy-carbonate deposits, represented by a wide range of facies, from sandstones to crinoidal limestones. In detail these deposits have been described by Horwitz and Rabowski (1922), Siemiradzki (1923), Rabowski (1954, 1959), Radwański (1959b), Wójcik (1959, 1981) and Jezierska et al. (2016). Several members and beds are distinguished within the formation (Lefeld et al., 1985). Its total thickness varies greatly, 
and reaches over $500 \mathrm{~m}$ in the Chochołowska Valley in the western part of the unit (Fig. 3; Wójcik, 1981; Lefeld et al., 1985), but does not exceed ten or so metres in its eastern part (east of the Kościeliska Valley), in the Kraków Gorge (Fig. 3; Jezierska et al., 2016) and in parautochthonous folds in the Rzędy pod Ciemniakiem area (Fig. 3). However, in the latter locations the thickness of the formation is probably tectonically reduced. The Dudziniec Formation occurs also as infillings of sedimentary dykes penetrating the Triassic substrate (Radwański, 1959a), as well as hosting neptunian dykes itself (Łuczyński and Jezierska, 2018).

The exact chronostratigraphy of the Dudziniec Formation remains unclear. Originally, based on scarce and mainly poorly preserved belemnite and brachiopod faunas, Horwitz and Rabowski (1922) determined the age of these deposits as Hettangian (Sinemurian?) through Bathonian. Based on the presumed Bajocian age of the overlying Smolegowa Formation, documented mainly in the Pieniny Klippen Belt (Birkenmajer, 1977), the upper limit of the formation is supposed to be of Aalenian age.

The onset of deposition of the Dudziniec Formation took place in a Tatricum domain already characterized by pronounced topographic variety. The base of the formation lies unconformably and erosively on the Triassic (Jezierska and Łuczyński, 2016). The allochthonous Giewont and Czerwone Wierchy units probably remained elevated through the whole Early Jurassic and acted as source areas for the carbonate lithoclastic components of the Dudziniec Formation that was deposited on the autochthonous unit (Rabowski, 1959; Kotański, 1961; Łuczyński, 2002). No Early Jurassic deposits have been recorded from the High-Tatric allochthonous units. In individual exposures, in the terrigenous component of Middle Jurassic crinoidal limestones (the Smolegowa Formation in the Ciemniak section of the parautochthonous area of the Kominy Tylkowe Unit, and the Krupianka Formation in the Mała Świstówka section in the Czerwone Wierchy Unit; Fig. 3) clasts of sandstone and sandy limestone lithologically resembling the Dudziniec Formation have been reported (Szulczewski, 1963b; Łuczyński, 1999). Such an occurrence could suggest that the area of deposition of the carbonate-sandy deposits of the Dudziniec Formation in the Tatra Mountains was not limited only to the autochthonous unit; this possibility had been noted by Passendorfer (1934) and Kotański (1961), but still lacks confirmation.

Furthermore, the area of the present-day autochthonous unit was not uniform, but embraced submerged parts with marine deposition across the Triassic/Jurassic boundary in the west (Chochołowska Valley region), and areas exposed, eroded and abraded prior to the Early Jurassic transgression in the east (Kościeliska Valley region). This division of the Kominy Tylkowe Unit into a deeper area on the west and a shallower area on the east prevailed during the whole Early Jurassic and is reflected by prominent lateral thickness variations in the Dudziniec Formation (Wójcik, 1981; Lefeld et al., 1985, Jezierska et al., 2016).

The influence of syndepositional tectonic activity on the development of the Dudziniec Formation unit has long been recognized. Z. Wójcik (1959) and K. Wójcik (1981) studied its deposits in the Chochołowska Valley region, and divided their sedimentary history into a number of cycles. An idealized complete cycle is composed of facies ranging from quartzitic sandstones, through mixed sediments consisting mainly of quartz, peloids and crinoids, to crinoidal limestones commonly with sponge spicules (spiculites, previously named as spongiolites). These authors attributed the origin of the cycles to a varied bottom morphology, caused by periodic uplift of some areas. The uplifted blocks were eroded, which resulted in an increase in supply of clastic material into the basin and in sedimentation of sandy facies. Crinoidal facies were in turn deposited at times of tectonic stability. Three main episodes of tectonically induced sandy deposition were recognized, separated by calm periods of mainly crinoidal sedimentation, although their exact timing remains unknown.

The control of recurrent episodes of syndepositional tectonic activity on deposition is indicated also by the facies distribution within the Dudziniec Formation in sections exposed in the Kościeliska Valley (Jezierska et al., 2016). This area represents settings located closer to the elevated source areas, reflected by smaller thicknesses, a greater contribution of detrital-sandy facies and their lower petrographic maturity, as compared with the Chochołowska region. The high-energy facies are represented by a wide lithological range including hybrid limestones, sandy-pebbly limestones and hybrid crinoidal limestones (Jezierska et al., 2016), all characterized by poor sorting. The composition of clasts which, apart from quartz grains and carbonate lithoclasts, are represented also by a substantial amount of alkaline feldspars, points to a varied source area and multiple sources.

Control of the sedimentary development during the Early Jurassic in the High-Tatric area by syndepositional block faulting in an extensional regime is indicated also by the occurrence of neptunian dykes (Fig. 6). In the Kościeliska Valley, the sandstones and sandy conglomeratic limestones in the lower part of the Dudziniec Formation host neptunian dykes filled by calcilutites, calcarenites and calcareous sandstones (Łuczyński and Jezierska, 2018). The development of fissures took place in multiple stages, with the same structures opening several times, as indicated by their complex architecture, the occurrence of internal breccias and the arrangement of the infilling sediments. Various types of infill came from multiple sources. The deposits infilling the neptunian dykes lack any fauna that would allow their age determination. However, their absence from the upper parts of the sections of the Dudziniec Formation, and the resemblance of some of the infills to characteristic sediments of the normal succession of the formation in the area , indicates that the dykes are most probably of Sinemurian to Pliensbachian age (Łuczyński and Jezierska, 2018).

In the Early Jurassic, after the differentiation of the Tatricum and Fatricum domains, the two units underwent different sedimentary histories, although in both cases marked by syndepositional tectonic instability. The Krížna succession is continuous across the Triassic/Jurassic boundary (Fig. 4), and the Rhaetian Fatra Formation passes upwards into the Hettangian-Synemurian(?) Kopieniec Formation with a diachronous lower boundary (Gaździcki, 1975, 1983, 2014b; Gaździcki and Iwanow, 1976; Gaździcki et al., 1979), representing shallow shelf settings. In the eastern part of the Tatra Mountains, it is overlain by shallow marine quartzitic limestones of the Koperszady (Med'odoly) Sandstone Formation (Lefeld et al., 1985; Popiołek et al., 2010; Uchman et al., 2014a) with its lower part referred to as the Baboš Quartzite Member (Iwanow, 1973; Popiołek et al., 2010). The provenance of quartz grains in these facies is not unequivocally determined, and may be associated with magmatic and metamorphic rocks; however, most probably they underwent a multistage history and are derived from erosion of Triassic clastic deposits from exposed parts of Tatricum or Hronicum (Turnau-Morawska, 1953, 1955; Popiołek et al., 2010). Once again, this underlines the topographic diversity within the Central Carpathian area during the early stages of the Early Jurassic.

The higher part of Lower Jurassic succession of Fatricum is represented by spotted limestones and marls of the Soltysia 
Marlstone Formation (Lefeld et al., 1985; Uchman et al., 2014b) - an equivalent of the Alpine Fleckenmergel facies (Wieczorek, 1995). Initially sedimentation was more unified and represented mainly by deep water facies then, not later than the Pliensbachian, the Križna Basin became divided into horsts and grabens by syndepositional block faulting. These events may be simultaneous and related to the episodes of faulting in the High-Tatric domain recorded by facies changes and the occurrence of neptunian dykes, although the exact correlation of particular events is not currently possible. Since the Pliensbachian, the horsts became places of variable sedimentation of specific facies, that differed from the Fleckenmergel variety prevailing in deeper areas. These deposits belong to the Huciska Limestone Formation (Lefeld et al., 1985; Jach, 2014). Their differentiation and sedimentary history are yet further reflections of the prevailing influence of syndepositional extensional tectonics on sedimentation and basin morphology during the Early Jurassic and the Early/Middle Jurassic transition on the Central Carpathian Block. The succession starts with spiculites (Jach, 2002) which, due to shallowing of some areas, were replaced by crinoidal limestones deposited in the vicinity of crinoidal meadows (Głuchowski, 1987) and interpreted as tempestites (Jach, 2005). A spectacular facies example of the Huciska Limestone Formation, the deposition of which was related to syndepositional tectonic activity, is the Upper Toarcian manganese layer with stromatolites that outcrops between the Chochołowska and Lejowa Valleys. Based on characteristic their faunal and mineralogical features, these deposits are interpreted as related to submarine hydrothermal vents associated with faults and fissures (Jach and Dudek, 2005). They are overlain by condensed Ammonitico Rosso-type red nodular limestones deposited on a submarine swell(s) (Wieczorek, 1983; Gradziński et al., 2004). Wieczorek (2001) considered these condensed horizons as one of the "turning points" in the passive margin evolution.

Jurassic deposits of the Hronicum domain are preserved in the Choč (Upper Sub-Tatric) Unit of the Tatra Mountains only sporadically (Fig. 4; Uchman, $2014 b)$. The Jurassic is almost entirely represented by the variously developed Sinemurian to Pliensbachian limestones of the Miętusia Formation, resting directly on the Triassic (Uchman and Tchoumatchenco, 1994). Their formation is interpreted to have been controlled by syndepositional tilting of fault-bounded blocks, the rotation of which lead to emergence and erosion of Triassic rocks (Uchman, 1993). Bahamian-type shallow water tropical carbonates are typical of the Lower Jurassic of the Western Tethys (Rychliński et al., 2018). The youngest deposits of the Upper Sub-Tatric Unit comprise red bioclastic limestones, most probably of Aalenian age (Uchman, 1988, 2014a).

All these features indicate that, during the Early Jurassic, extensional syndepositional tectonics connected with opening of the Vahic Ocean controlled deposition in all palaeogeographical domains represented in the Tatra Mountains.

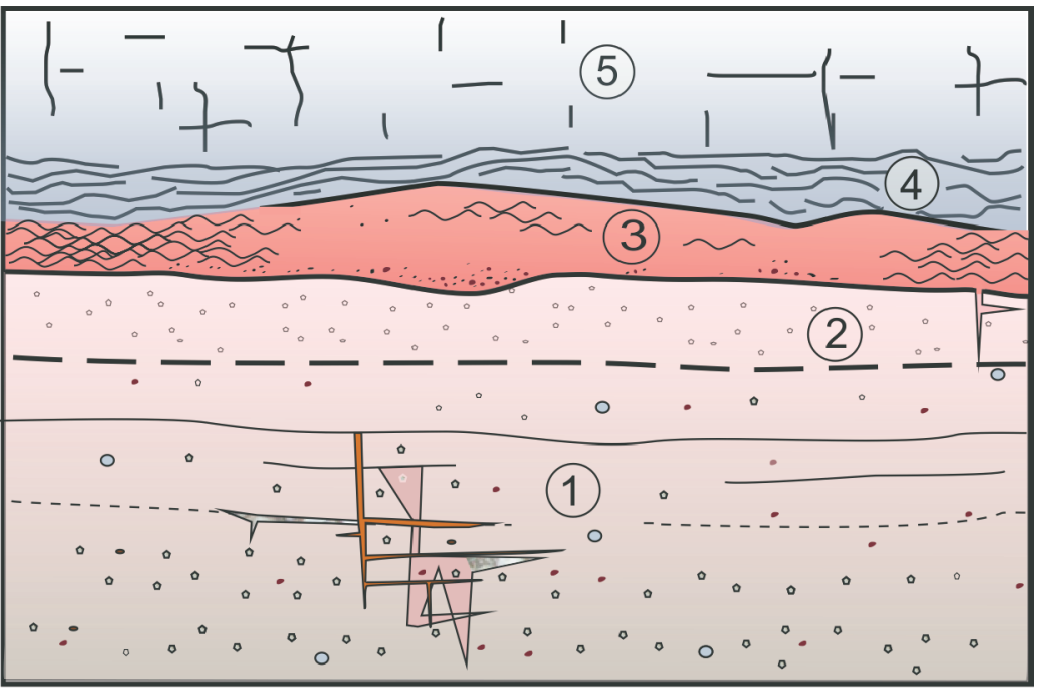

faintly bedded sandy-carbonate deposits (sandstones to crinoidal limestones) of the Dudziniec Formation (Hettangian-Aalenian?)

white and pink coarse crinoidal limestones of the Smolegowa Formation (Bajocian)

red crinoidal and nodular limestones of the Krupianka Formation (Bathonian)

wavy bedded limestones and marls of the bottom part Raptawicka Turnia Formation (Callovian) massive limestones of the Raptawicka Turnia Formation (Oxfordian - Tithonian) sharp-edged neptunian dykes filled mainly with Krupianka crinoidal limestones

sharp-edged neptunian dykes

filled with carbonate-clastic deposits

smooth-edged systems of neptunian dykes filled with carbonate silt

dykes filled with calcite cements

internal breccias

- parts of host-rocks densely penetrated by neptunian dykes and associated structures

Fig. 6. Idealized spatial relations between Jurassic lithosomes and neptunian dykes in the Kominy Tylkowe Unit (partly after Łuczyński, 2002)

THE TIME OF DEPOSITION OF THE SMOLEGOWA FORMATION (BAJOCIAN?)

The Smolegowa Formation is uniformly developed across the High-Tatric succession. In all units it is represented by light grey to pink, coarse-grained crinoidal limestones with a minor admixture of Triassic lithoclasts and quartz grains (Lefeld et al., 1985; Łuczyński, 2002, 2014a). Traditionally, these deposits have been termed "white Dogger crinoidal limestones" by Uhlig (1897) and "white Bajocian crinoidal limestones" by Horwitz and Rabowski (1922), Andrusov (1958, 1959), Rabowski (1959) and Kotański (1959a, 1961). A Bajocian age has been determined by Horwitz and Rabowski (1922) based on their brachiopod fauna.

Jurassic crinoidal limestones are a common facies in the Jurassic of various Tethyan basins (Jenkyns, 1971). Similarly 


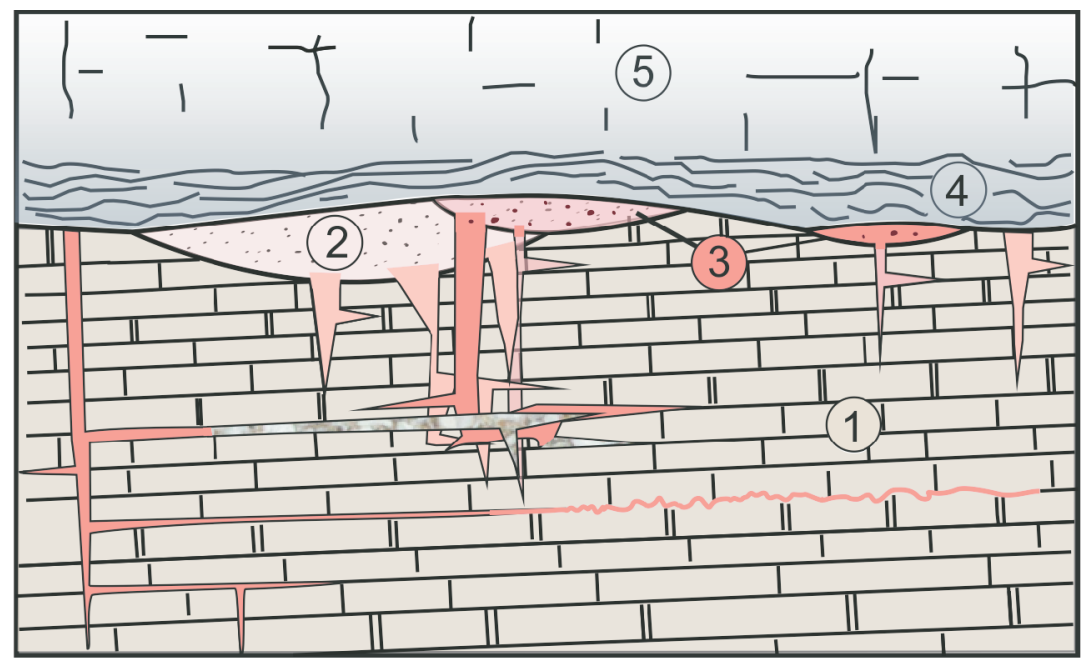

shallow-water distinctly bedded limestones and dolomites (Triassic)

white and pink coarse crinoidal limestones of the Smolegowa Formation (Bajocian)

red crinoidal and nodular limestones of the Krupianka Formation (Bathonian)

wavy bedded limestones and marls

of the bottom part Raptawicka Turnia Formation (Callovian)

(5) massive limestones

of the Raptawicka Turnia Formation (Oxfordian - Tithonian)

F sharp-edged neptunian dykes

filled mainly with Smolegowa and Krupianka crinoidal limestones

smooth-edged systems of neptunian dykes

filled with red carbonate silt

$\longrightarrow$ dykes filled with calcite cements

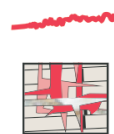

pressure solution structures associated with neptunian dykes

internal breccias

- parts of host-rocks densely penetrated by neptunian dykes and associated structures

Fig. 7. Idealized spatial relations between Triassic and Jurassic lithosomes and neptunian dykes in the Czerwone Wierchy and Giewont units (partly after Łuczyński, 2002)

developed deposits (though reaching much greater thicknesses and yielding ammonites) are present also in the Pieniny region. The Smolegowa Formation is one of the stratigraphical units incorporated into the High-Tatric lithostratigraphic division in a scheme earlier devised for the Pieniny Klippen Belt (Birkenmajer, 1977). In the Pieniny, its exact age limits within the Bajocian have been precisely determined (Wierzbowski et al., 1999; Krobicki and Wierzbowski, 2004), though these results cannot be easily transposed into the Tatric successions.

The Smolegowa Formation is developed as massive limestones, with faint bedding observed only in parts of the Kominy Tylkowe Unit (Rzędy pod Ciemniakiem and Chochołowska Valley; Fig. 3), in which it attains its maximum thickness of up to $30 \mathrm{~m}$ (Kotański 1959a). In parts of the autochthonous unit (Dolina Chochołowska, Wąwóz Kraków), the Smolegowa limestones occur in a continuous succession of the Dudziniec Formation (Wójcik, 1981; Lefeld et al., 1985; Łuczyński, 1999). In the Giewont and Czerwone Wierchy units, the formation is preserved only in places as laterally discontinuous lenticular bod- ies of maximum thickness not exceeding a few metres (Fig. 7; Łuczyński, 2002). In these units, the Bajocian rests directly on various Triassic strata with a small angular unconformity, best visible in the Giewont Unit and referred to as a paraconformity (Jezierska and Łuczyński, 2016).

The deposits of the Smolegowa Formation are composed almost pure encrinites composed solely of recrystallized crinoids, commonly with preserved original pentagonal or circular shapes of individual ossicles (Łuczyński, 2002), only locally accompanied by brachiopod debris. The high taxonomic diversity, mass occurrence and preservation state of the crinoid material of the Smolegowa limestones all point to favourable conditions for the development of crinoidal meadows (Głuchowski, 1986, 1987) and for in situ deposition in their direct vicinity. At Rzędy pod Ciemniakiem (Fig. 3), the formation starts with a basal conglomeratic layer rich in ferruginous (hematite) encrustations, and large (diameter exceeding $1 \mathrm{~cm}$ ) ferruginous clasts and nodules (Jezierska and Łuczyński, 2016). Such a phenomenon, present also in the Lower Sub-Tatric succession (Jach et al., 2014), indicates breaks in deposition and development of omission surfaces preceding the deposition of encrinites. Similar layers at the base of the Smolegowa Formation occur also in many successions in the Pieniny Klippen Belt (Krobicki and Wierzbowski, 2004; Krobicki, 2019), and are interpreted as related to the development of the Czorsztyn Ridge.

Apart from the conglomeratic layer described above, the encrinites of the Smolegowa Formation contain only a sparse admixture of terrigenous material (Łuczyński, 1999, 2002; Jezierska and Łuczyński, 2016). This is composed of carbonate lithoclasts (limestones and dolomites), quartz grains and ferruginous clasts, in various amounts and proportions, occurring in all High-Tatric tectonic units. All the components can be identified as coming from local sources and derived from various clastic and carbonate parts of the Triassic sequences of the High-Tatric succession. The extraclast content ranges between $1 \%$ in the Czerwone Wierchy Unit and $3.7 \%$ in the Kominy Tylkowe Unit (Łuczyński, 1999).

The white and pink coarse-grained crinoidal limestones identified as the Smolegowa Formation occur also in numerous neptunian dykes penetrating the Triassic limestones in all three High-Tatric tectonic units (Fig. 8; Łuczyński 2001). In the Kominy Tylkowe Unit (Raptawicka Turnia section), to a very limited extent they are found also in the topmost part of the Dudziniec Formation. The dykes filled with the Smolegowa Formation are usually characterized by sharp-edged, clean walls (devoid of any encrustations, cementation and traces of corrosion), which points to the main role of mechanical processes in their origin. They are most common in the Czerwone Wierchy Unit, occurring in many areas, in which this formation is absent in the normal stratigraphic column (e.g., Niżnia Świstówka in the Mała Łąka Valley; Fig. 3). This is another indication that the 


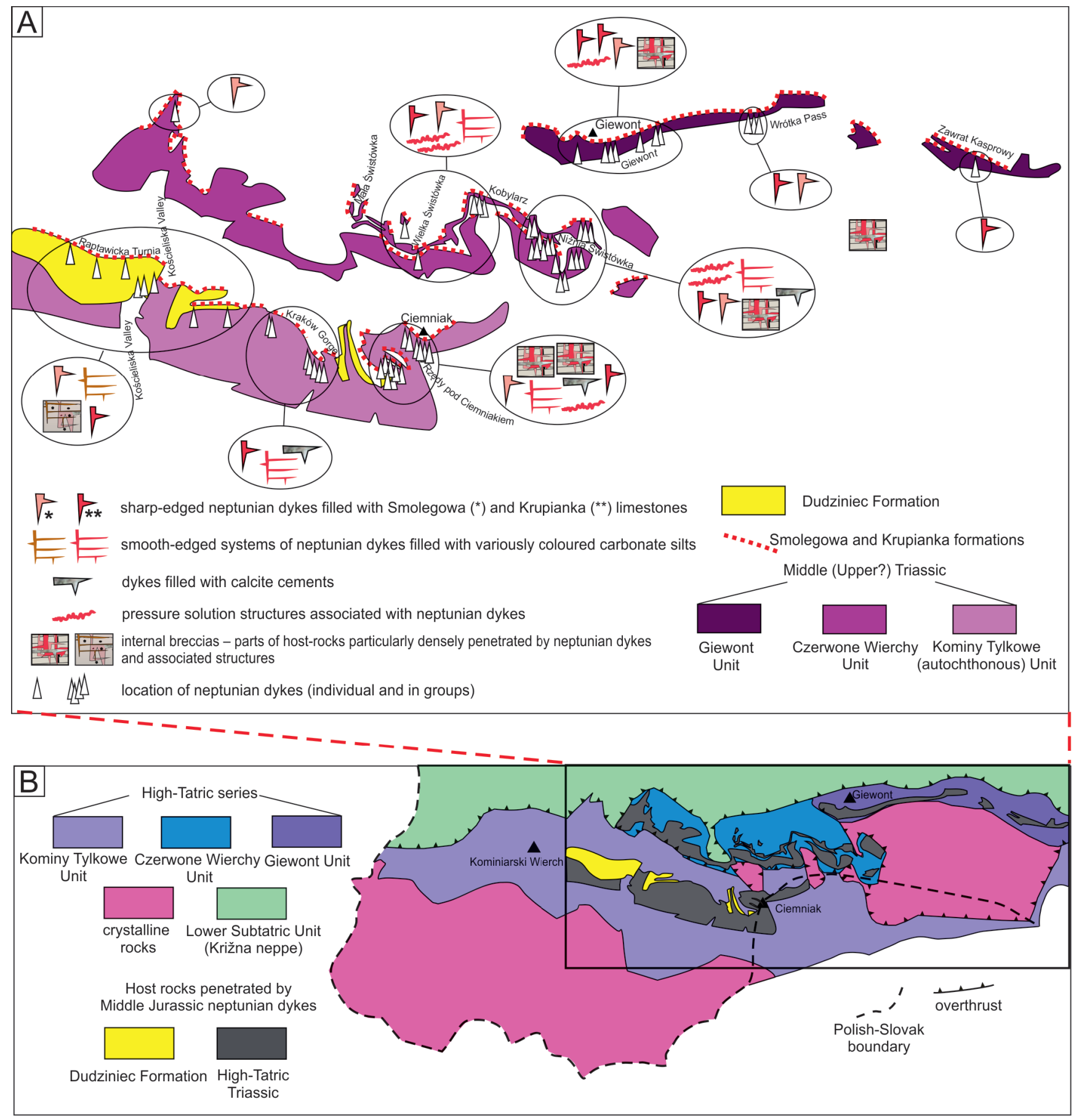

Fig. 8. Distribution of various types of neptunian dykes filled with Jurassic deposits penetrating Triassic and Lower Jurassic host rocks (A) and location of the host rocks in particular units of the High-Tatric succession (B)

area of deposition of the Smolegowa limestones was larger than their present distribution, and that the lenticular shape of most of the lithosomes is an erosional phenomenon. On the other hand, if the High-Tatric allochthonous units are interpreted to be the source areas of the terrigenous admixture present in the crinoidal limestones, at least some parts of the area must have remained uplifted during some periods of their deposition.

Compilation of these observations leads to a relatively complicated regional palaeogeographical picture of the High-Tatric area during the Bajocian, which however due to lack of precise stratigraphical evidence cannot be more closely constrained in time (Fig. 9). The Bajocian transgression, which most probably flooded the whole High-Tatric area, was preceded by rotation of substrate blocks, as is indicated by a paraconformable contact of the Smolegowa Formation with the underlying deposits, most clearly visible in the Giewont Unit. Another period(s) of tectonic instability is marked by the formation of neptunian dykes. The formation of extensional fissures took place in the Triassic solid substrate under the cover of recently deposited loose crinoidal deposits, which were injected into them at the moment of their opening (Łuczyński, 2001a; see Winterer et al., 1991). Formation of the neptunian dykes was associated with the activity of syndepositional extensional faults, responsible for the differen- 
tiation of the basin's topography during deposition and for the lateral thickness variations in the Smolegowa crinoidal limestones.

The stratigraphy and sedimentology of the Middle to Upper Jurassic of the Lower Sub-Tatric (Krížna) Unit has been summarized by Jach et al. (2014) and by Jach and Reháková (2019), who referred to the Fatricum domain at that time as a pull-apart basin with a thinned continental crust, emphasizing the influence of tectonic activity on its sedimentary history. In the Bajocian, sedimentation differed between the eastern and western parts of the area (Jach and Uchman, 2014). In the west (exposures in the Western Tatra Mountains) the discontinuous succession represents elevated horst areas (Uchman, 2014a) and is represented by shallow water crinoidal and Bositra limestones (Jach, 2007). In the east (Kopy Soltysie region and Bielskie Tatry), the facies are characteristic of deeper basinal settings and are developed as spotted limestones and marls of the Soltysie Marlstone Formation (Fleckenmergel facies), the deposition of which continued across the Lower/Middle Jurassic boundary (Lefeld et al., 1985; Uchman, 2014a). From this time on, due to gradual deepening of the whole area, and because of cessation of syndepositional tectonic activity, the deposition became more unified across the Krížna Unit (Jach and Reháková, 2019). This deepening and facies unification precedes similar processes (although differently expressed) in the High-Tatric Unit.

The stratigraphic column of the Upper Sub-Tatric Unit lacks Jurassic deposits younger than Aalenian (Lefeld et al., 1985; Uchman, 2014a).

\section{THE TIME OF DEPOSITION OF THE KRUPIANKA FORMATION} (BATHONIAN)

The interval with most profound evidence of the variable influence of syndepositional tectonic activity on the depositional development of the High-Tatric succession is the timespan between the deposition of the Smolegowa Formation encrinites and the onset of deposition of the Raptawicka Turnia pelagic limestones. In the sedimentary record this is represented by the Krupianka Formation. Traditionally its deposits have been referred to as "red Dogger crinoidal limestones" by Uhlig (1897) and as "red Bathonian crinoidal limestones" by Horwitz and Rabowski (1922), Passendorfer (1936, 1938), Rabowski (1959), Kotański (1961) and Szulczewski (1963a, 1968). Based on the rich ammonite fauna from Wielka Świstówka in the Czerwone Wierchy Unit ("Świstówka Passendorfera" section * in Fig. 3), they have been stratigraphically assigned to the Middle Bathonian Hecticoceras retrocostatum Zone (Passendorfer, 1936, 1938). Their Middle Bathonian age has also been stated by Galácz and Matyja (1999), though again based on material from the same locality. On this basis, a Bathonian age has been ascribed to the whole Krupianka Formation occurring in the High-Tatric succession (Lefeld et al., 1985). Taking into account the lack of any precise stratigraphical data from other locations, this assumption may be weakly based. Moreover, the Krupianka Formation is a unit incorporated into the High-Tatric scheme for the Pieniny Klippen Belt, where it is developed as red crinoidal limestones attaining a substantial thickness (Birkenmajer, 1977). Much data suggests that the age of the Krupianka formation in the Pieniny area is not Bathonian, as previously postulated, but rather falls into the Upper Bajocian (Wierzbowski et al., 1999; Krobicki and Wierzbowski, 2004; Segit et al., 2015; Ivanova et al., 2019). This makes a synchronous Bathonian age for all the separate exposures of the Krupianka Formation in different tectonic units of the High-Tatric succession even more doubtful. Nonethe- less, in the present paper, the formation is treated as representing the Bathonian.

As in the case of the Smolegowa Formation encrinites, particularly in the allochthonous units, the Krupianka Limestones usually occur as laterally discontinuous bodies with a variable but very limited thickness, only rarely exceeding one metre (Łuczyński, 2002; Jezierska and Łuczyński, 2016). This small thickness is partly an effect of intense chemical compaction of the deposits during their late diagenesis (Łuczyński, 2001b). However, unlike in the case of the Bajocian limestones, the lenticular shape of the lithosomes, at least in some of the exposures, can be interpreted as a depositional structure of fossil "submarine dunes" (e.g., Mišík, 1964; Jenkyns, 1971). In other places, however, the characteristic shape probably resulted from differential erosion that left the Krupianka Limestones preserved only in palaeodepressions.

The unconformity at the base of the Krupianka Formation shows great variability (Jezierska and Łuczyński, 2016), mainly due to the spatial discontinuity of both the Smolegowa and the Krupianka limestones (Fig. 7) and due also to the occurrence of the Dudziniec Formation only in the autochthonous unit. Therefore, in various areas, the Bathonian rests directly on the Triassic (all three tectonic units; e.g. the Wąwóz Kraków autochthonous unit, the Wielka Świstówka-Czerwone Wierchy Unit, and the Zawrat Kasprowy-Giewont Unit), on the Dudziniec Formation (only the autochthonous unit; e.g. Wąwóz Kraków 1), or on the Smolegowa Formation (two tectonic units; e.g. the Rzędy pod Ciemniakiem - autochthonous unit, and the Giewont - Giewont Unit). In all cases the contact shows an erosional character, emphasized by the lenticular shapes of the lithosomes, and in many places the Bathonian deposits fill local depressions.

The differentiation of the High-Tatric area in the Bathonian, caused by syndepositional fault activity, is reflected by facies differences between particular tectonic units. In the Giewont Unit, the Krupianka Formation is represented by red crinoidal limestones (Lefeld, 1957; Sieciarz, 1963; Łuczyński, 2002), in the Czerwone Wierchy Unit mainly by condensed ferruginous deposits commonly with stromatolites and occasionally with an abundant ammonite and belemnite fauna (Grochocka-Rećko, 1963; Kostiukow, 1963; Szulczewski, 1963b; Łuczyński, 2002), whereas in the Kominy Tylkowe Unit in most exposures it is developed as (stylo)nodular limestones (Łuczyński, 2002). All three lithofacies have been subjected to strong pressure dissolution and chemical compaction (Łuczyński, 2001b), the intensity and character of which differed between different tectonic units. Although the present facies differences are accentuated by late diagenesis, all the varieties are characterized by a red colour and the occurrence of crinoids. Their present-day development is partly an effect of these processes, with the crinoidal limestones being the least altered, and thus their pre-compactional differences were less evident than they are today.

The Krupianka Limestones of the Giewont Unit and particularly of the Czerwone Wierchy Unit include abundant evidence of internal breaks in deposition, such as erosional surfaces and condensed horizons (Lefeld, 1957; Grochocka-Rećko, 1963; Kostiukow, 1963; Szulczewski, 1963b; Łuczyński, 2002; Jezierska and Łuczyński, 2016). For example, in the Wrótka Pass section of the Giewont Unit (Fig. 3), a condensed belemnite- and crinoid-rich deposit is truncated by an intraformational flat abrasion surface (Łuczyński, 1999). The character of the surface, that evenly cuts the sediment and the belemnite rostra, indicates abrasion of completely lithified deposits, which in turn indicates that the non-depositional and/or erosional episodes 
were long-lasting. In a number of areas (e.g., Giewont, Mała Świstówka, Wielka Świstówka; Fig. 3) stromatolite horizons occur, marking condensation episodes (Szulczewski, 1963a, b, 1968; Łuczyński, 1999, 2002). Moreover, in the Świstówka Pasendorfera section in Wielka Świstówka, the stromatolite horizon is overlain by a condensed layer rich in ammonites. The occurrence of such condensed horizons at certain levels of the sedimentary successions is often considered to represent crucial turning points in the depositional development on passive margins of various Tethyan basins (Dumont et al., 1996; Wieczorek, 2001).

The Krupianka Limestones in all their lithological varieties contain a fairly rich terrigenous admixture (Łuczyński, 2002; Jezierska and Łuczyński, 2016). It is much more abundant and coarser than in the Smolegowa encrinites, which indicates that the erosion was more intense, and the source areas were closer. The admixture is composed of limestone and dolomite lithoclasts, which can be identified as derived from the High-Tatric Triassic, quartz grains probably coming mainly from erosion of the Dudziniec Formation in the Kominy Tylkowe Unit, and ferruginous clasts indicating intraformational erosion and reworking. Reflecting differences in the main source areas, the composition of the clastic admixture differs between different tectonic units (Jezierska and Łuczyński, 2016). As compared with the entire High-Tatric Bathonian, the quartz grains are proportionally more abundant in the autochthonous unit (direct vicinity of the carbonate-clastic Lower Jurassic deposits), whereas ferruginous clasts are especially common in the Czerwone Wierchy Unit (area of most prominent evidence of condensation and/or non-deposition). In the Giewont Unit, the composition of the terrigenous admixture is very similar to that calculated for the whole High-Tatric succession.

The reconstruction of the palaeogeographic and palaeotectonic history of the High-Tatric area during the Bathonian is too a great extent based also on the analysis of neptunian dykes filled with deposits of the Krupianka Formation. As noted above, the Krupianka limestones are preserved only sporadically in the normal stratigraphic column, both laterally and in vertical sections. In such an incomplete record, characteristic of times of fragmentation of carbonate platforms during rifting, the study of unconformities and neptunian dykes can shed light on the processes that took place in the intervals hidden in the gaps (Clari et al., 1995; Marino and Santantonio, 2010). Commonly the infills of dykes are the only preserved deposits representing particular episodes of an area's development, yielding unique information (e.g., Lehner, 1991; Winterer and Sarti, 1994; Aubrecht and Kozur, 1995; Schlögl et al., 2009; Aubrecht and Schlögl, 2011; Wendt, 2017).

Dykes with variously developed deposits associated with the Krupianka Formation are present in all the High-Tatric tectonic units (Łuczyński, 2001a). Systems of interconnected dykes and sills are hosted mainly by the Middle Triassic carbonates and in the Kominy Tylkowe Unit; they occasionally penetrate also the topmost part of the Dudziniec Formation. To this group belong fissures and voids containing red crinoidal limestones, but also extensive systems of structures filled with very fine red, unfossiliferous carbonate silt - the "rot pelit". The origin of the latter is not entirely clear, however, most probably these are the finest fractions of the Krupianka Limestones that penetrated deep into the voids and were depleted from coarser fractions due to the sieve effect. Such an interpretation is suggested by the shapes and dimensions of the very thin interconnected networks of thin fissures penetrating deep into the underlying Triassic strata. In the Czerwone Wierchy Unit, structures filled with red micrite occur $>150 \mathrm{~m}$ below the base of the Jurassic (Łuczyński, 1999). Often they are developed as sills running along bedding planes within the Triassic (Anisian) limestones and dolomites (Fig. 8), and pass laterally into fissures filled with calcite cement (presumably in those parts of the fissures which the sediment did not reach) or fade away as pressure solution structures, such as dissolution seams (Łuczyński, 2001a, b; see also Mišík, 1998).

In some localities the dykes associated with the Krupianka Formation are interconnected with dykes filled with Smolegowa crinoidal limestones, which points to repeated opening of the same fissures. Recurrent opening of the void systems and movement within them, associated with repeated fracturing of the brittle substrate due to episodic tectonic instability, is indicated also by the occurrence of internal breccias (Fig. 8). Nests of such breccias occur in places that are particularly densely cut by consecutive systems of dykes filled with various deposits. All this marks episodes of intense substrate fracturing associated with extensional tectonic movements taking place in the Tatricum domain. At least two such profound episodes took place - after the deposition of the Smolegowa limestones and during the deposition of the Krupianka limestones.

In contrast to the dykes filled with the deposits of the Smolegowa Formation, the dykes associated with the Krupianka limestones are often characterized by smooth walls devoid of sharp edges, which suggests an important role of dissolution processes in their formation. However, more prolonged subaerial exposition seems unlikely, as is indicated by the stable oxygen and carbon isotopes of deposits that infill them. The $\delta^{13} \mathrm{C}$ values are between 3.2 and $3.3 \%$, and the $\delta^{18} \mathrm{O}$ is around $-2 \%$ for both the Smolegowa and the Krupianka limestones filling the dykes (for detailed data see Łuczyński, 1999, 2001a). These results fall within the range characteristic of marine waters of normal temperature and salinity (e.g., Gruszczyński, 1998; Kasting et al., 2006; Prokoph et al., 2008). This indicates good communication between the dykes and the sea bottom at the time when they were being filled with deposits.

On the other hand, other infillings of the fissures, such as red micrite (carbonate silt) and various kinds of palisadic, radiaxial and blocky calcite cements, are depleted in $\delta^{18} \mathrm{O}$ (ranging between -2.5 and $-8 \%$ ) in relation to other Middle Jurassic neptunian dykes described from other regions (e.g., Winterer et al., 1991; Winterer and Sarti, 1994; Mišík et al., 1994; Wall and Jenkyns, 2004). This may result from three co-occurring processes. Firstly, the fine carbonate silt and calcite cements occupy the more remote parts of the extensive systems of fissures deeply penetrating the substrate, that could have been subjected to circulation of hydrothermal waters (Hsü, 1983; Matyszkiewicz et al., 2016). In this case, the strongly negative $\delta^{18} \mathrm{O}$ values of the cements would indicate elevated temperatures of their precipitation. Secondly, depletion of the heavy oxygen isotope can be an effect of late diagenesis, particularly of pressure dissolution that took place mainly along horizontal planes. This is supported by the strongly negative $\delta^{18} \mathrm{O}$ results $(-12 \%)$ obtained for the residue of dissolution seams into which the sills laterally pass. Thirdly, the timespan represented by the dykes described (Bajocian/Bathonian boundary interval) is coeval with the most profound isotopic excursion in the Jurassic (Gruszczyński, 1998; O'Dogherty et al., 2006), characterized by particularly low $\delta^{13} \mathrm{C}$ and $\delta^{18} \mathrm{O}$ values. The distinctly positive $\delta^{13} \mathrm{C}$ values of red silts and calcite cements (between 2.4 and 2.9\%o) excludes their speleothem and karstic origin.

The base of the Krupianka Formation is an erosional unconformity in all High-Tatric tectonic units (Jezierska and Łuczyński, 2016), regardless of the underlying deposits (Triassic, Dudziniec or Smolegowa Formations). Removal of the Bajocian crinoidal limestones from large parts of the Tatricum 
Time of deposition of the Smolegowa and Krupianka formation
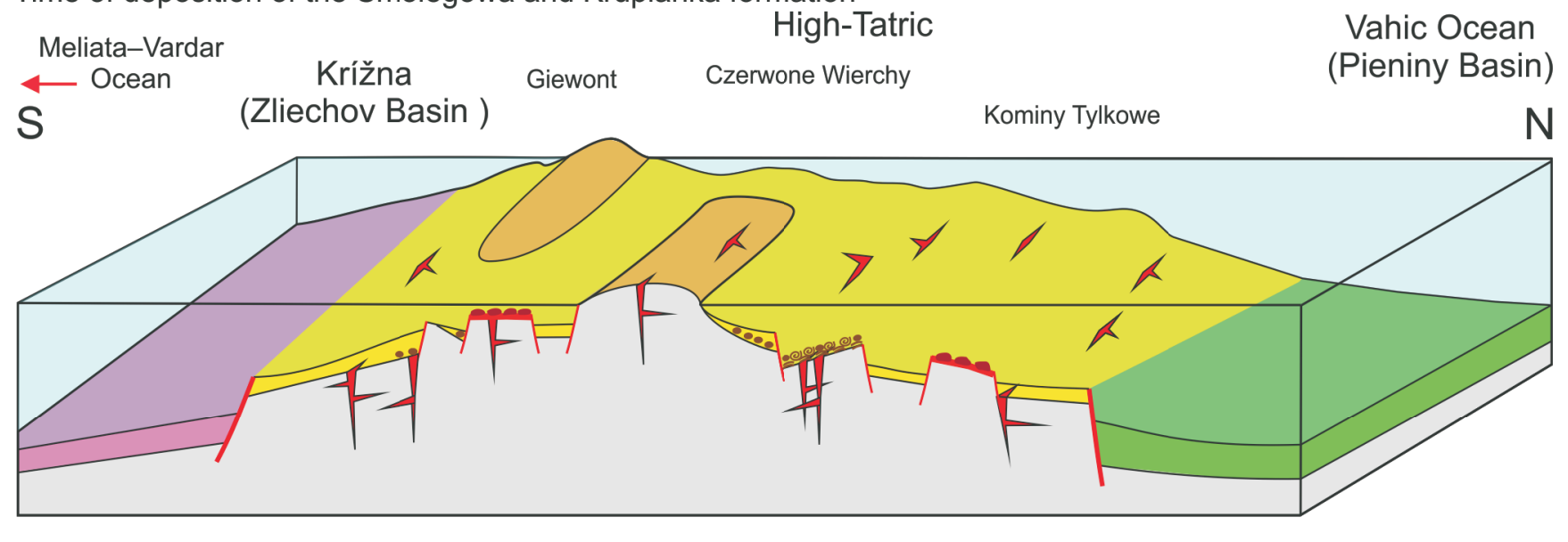

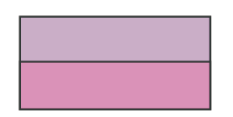

Zliechov Basin

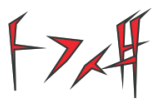

neptunian dykes

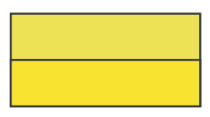

High-Tatric Basin

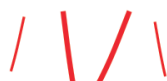

syndepositional faults

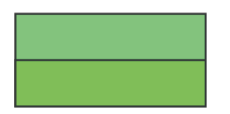

Pieniny Basin

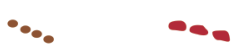

terrigenous material elevated area
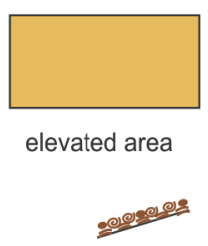

condenced horizons

Fig. 9. The High-Tatric (Tatricum) domain and the surrounding areas during deposition of the Smolegowa and Krupianka formations (Bajocian-Bathonian)

domain is indicated by the occurrence of neptunian dykes filled with the Smolegowa Formation in areas that lack the Bajocian in the normal stratigraphic column. Most probably, the whole High-Tatric area became subaerially exposed and subjected to erosion, which reached various levels. Some parts of the High-Tatric area remained emergent also after the following onset of deposition and became sources of the terrigenous admixture present in the Krupianka limestones (Fig. 9). During the entire time of sedimentation of the Krupianka Formation, the High-Tatric area acted as a constantly changing patchwork of elevated and submerged areas. Periods of deposition were interrupted by episodes of intraformational erosion, indicated by internal erosional surfaces, and also by the occurrence of reworked intraformational ferruginous clasts (Łuczyński, 2002). Recurrent tectonic instability led also to the formation of neptunian dykes and internal breccias, some of which are composed of multiple generations of sediments and cements. The occurrence of neptunian dykes filled with sediments associated with the Krupianka Formation also in those areas in which the Bathonian is missing in the normal stratigraphic column is yet another symptom of the intertwining of episodes of erosion and deposition. The topographic differentiation of the area is reflected also by the replacement of uniformly developed crinoidal limestones of the Smolegowa Formation by diverse facies of the Krupianka Formation.

The internal palaeogeographic picture of the High-Tatric domain during the deposition of the Krupianka Formation, emerging from the facies distribution, completeness of the sections and occurrence of neptunian dykes, is very complicated. Lack of precise stratigraphy hinders the possibility of accurate correlation of the sections, and thus of putting all the phenomena into proper stratigraphical order. Nonetheless, the sedimentary record of the times between the end of deposition of the Smolegowa limestones and prior to the onset of deposition of the Raptawicka Turnia limestones provides plentiful evidence of intense extensional tectonic activity on the southern side of the Vahic Ocean occupied by the Tatricum domain.

In the Lower Sub-Tatric Unit, the overall deepening pulse, which started in the Bajocian, continued during the Bathonian, when it became more distinct and uniform. A variety of different facies ascribed to various settings of a diverse palaeotopographic environment (see above) was replaced by spotted and nodular limestones followed by radiolarites (Jach, 2007; Jach and Uchman, 2014; Jach and Reháková, 2019). The radiolarite sedimentation of the Sokolica and Czajakowa formations (sensu Lefeld et al., 1985) and of the Ždiar Formation (sensu Polák et al., 1998), starting in the Bathonian and lasting until the Upper Kimmeridgian (Jach et al., 2012; Jach and Reháková, 2019), was uniform across the whole Zliechov Basin (Križna Unit). These facies mark the cessation of the syndepositional tectonic activity in the area. Both these processes (deepening and facies unification) preceded similar phenomena taking place in the Tatricum domain, in which they started probably not earlier than in the Callovian.

MIDDLE JURASSIC PERIOD OF DEPOSITION OF THE RAPTAWICKA TURNIA FORMATION (CALLOVIAN)

The variously developed deposits of the Krupianka Formation are truncated by a prominent unconformity surface in all High-Tatric tectonic units (Łuczyński, 2002; Jezierska and Łuczyński, 2016). The formation's discontinuous character of preservation, which in some areas is limited only to infills of neptunian dykes, points to a break in deposition and/or erosion following the sedimentation of red crinoidal, ferruginous and nodular limestones across the whole area. After that episode, the Tatricum domain was subjected to rapid drowning, which is reflected by a distinct facies contrast with the overlying deposits of 
A Generallised Jurassic succession of the High Tatric series

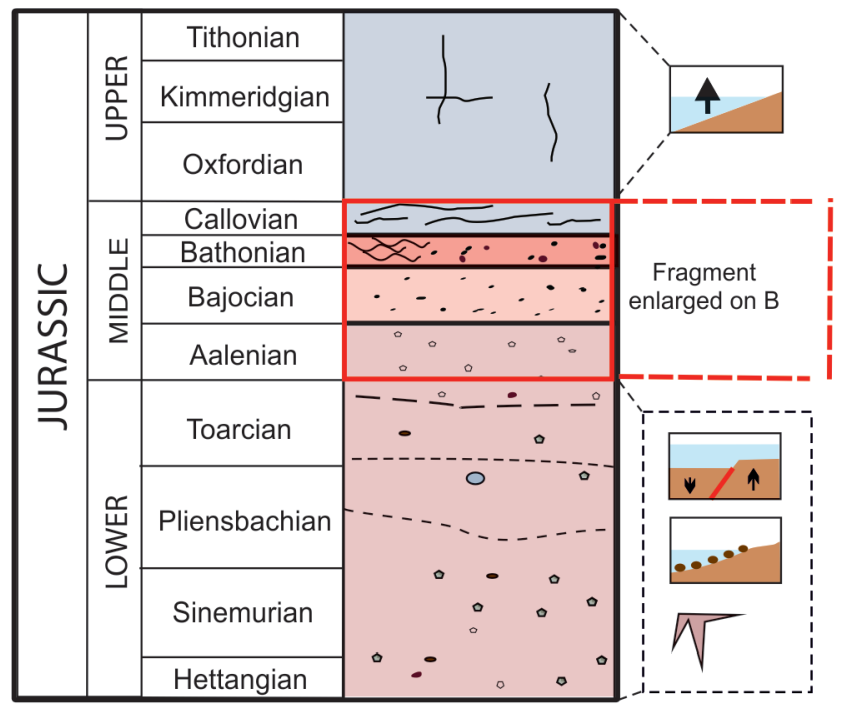

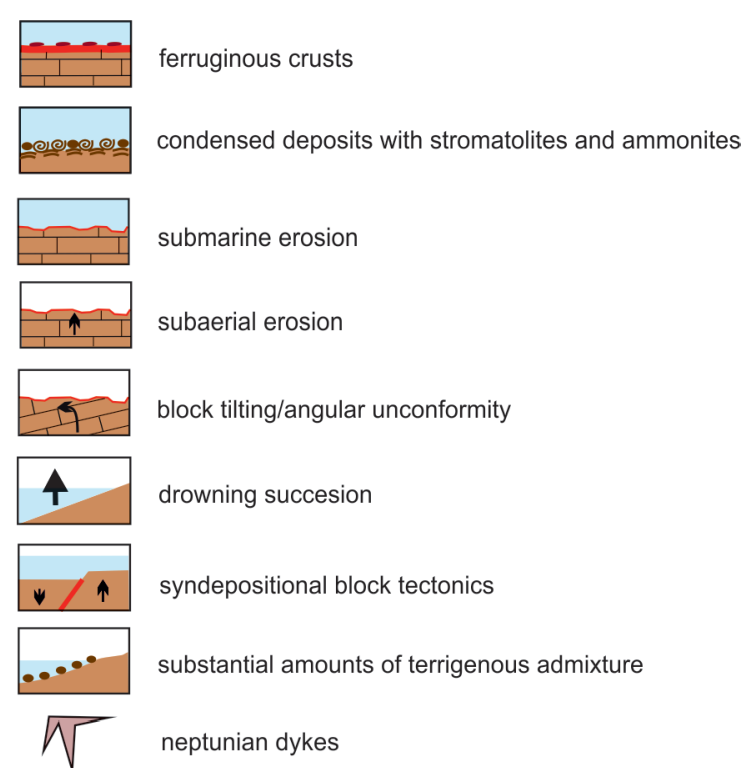

B Middle Jurassic of the High-Tatric series

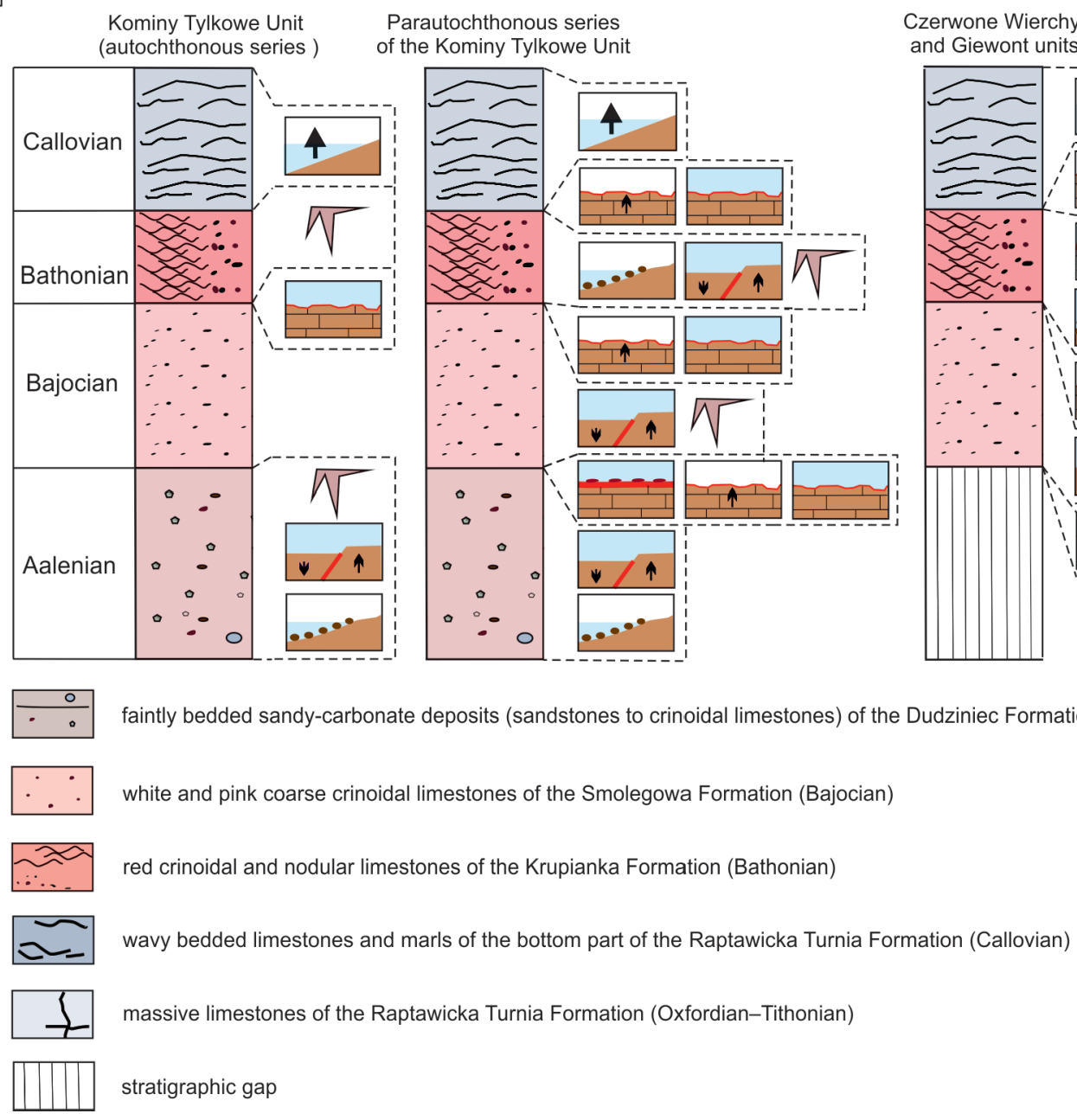

Fig. 10. Time and space distribution of tectonically induced phenomena and features recorded in the High-Tatric Jurassic of the Tatra Mountains 
the Raptawicka Turnia Formation. The contact of the Raptawicka Turnia formation with the underlying deposits has been interpreted as a drowning unconformity (Jezierska and Łuczyński, 2016; cf.: Marino and Santantonio, 2010; Godet, 2013).

The Callovian through Hauterivian Raptawicka Turnia Formation, with a thickness of $\sim 100 \mathrm{~m}$, is generally uniformly developed across the whole High-Tatric area (Lefeld et al., 1985; Uchman, 2014a), building many of the prominent mountain massifs, particularly in the Western Tatra Mountains (Bac-Moszaszwili et al., 1979; Łuczyński, 2014b; Łuczyński and Jezierska, 2017). Most of the formation is represented by massive or faintly bedded grey pelitic limestones with peloids and pseudo-oolites (Lefeld et al., 1985). Sedimentation of thick sequences of this formation was possible due to a considerable increase in accommodation space due to a global sea-level rise. Its lowermost part is developed as wavy-bedded greenish deposits consisting of limestone beds interbedded with clayey-marly layers, with scarce coarser terrigenous material (Łuczyński, 2002), and with a Callovian ammonite fauna (Horwitz and Rabowski, 1922; Passendorfer, 1936, 1938). This part of the formation, although present in all High-Tatric units, is missing at some localities (Łuczyński, 2002; Jezierska and Łuczyński, 2016). In the Kominy Tylkowe Unit (both in its autochthonous and parautochthonous parts), a Czorsztyn Limestone Member has been distinguished in the lower part of the formation (Lefeld et al., 1985). It is developed as pink nodular limestones (Kotański, 1961; Szulczewski, 1965), resembling the stylonodular variety of the Krupianka Formation in the same area. This unit has been adopted from the Pieniny Klippen Belt lithostratigraphic scheme, in which the Czorsztyn Limestones occur in the rank of a formation (Birkenmajer, 1977). The exact age of the Czorsztyn Member remains uncertain, but is considered to be Upper Callovian to Lower Oxfordian (Lefeld et al., 1985). This, however, no longer corresponds to the age of the Czorsztyn limestones in the Pieniny area, the deposition of which started already in the Bajocian (Wierzbowski et al., 1999; Krobicki and Wierzbowski, 2004; Segit et al. 2015). In those sections, in which the bottom wavy-bedded limestone and marly part of the Raptawicka Turnia Formation is missing (Kotański, 1961; Łuczyński, 2002), it is very difficult to distinguish the Czorsztyn limestones from the nodular variety of the Krupianka Formation.

A significant influence of syndepositional extensional tectonics on the sedimentary and facies development of the High-Tatric area, so characteristic of the earlier phases, had ceased altogether with the onset of the deposition of the Raptawicka Turnia Formation (Łuczyński, 2002, 2014b; Fig. 10). Accessory amounts of terrigenous clasts present in the lowermost (Callovian?) wavy-bedded part of the formation suggests the presence of some minor local source areas inherited after the Bathonian interval of topographical differentiation, which were elevated and eroded. Stratigraphically higher, these facies are replaced by thick, massive pelagic limestones reflecting burial of the Middle Jurassic palaeorelief.

In the Callovian, and generally also later throughout the Late Jurassic, the Tatricum domain, although marked by pelagic open-marine deposition, remained a relatively elevated area as compared with the domains located north and south (Fig. 10). In both the Zliechov Basin, represented by the Lower Sub-Tatric Unit, and in the Pieniny Basin (part of the Vahic Ocean) represented by the Pieniny Klippen Belt successions, deep-water sedimentation of mainly radiolarites prevailed (Jach and Reháková, 2019; Bąk and Bąk, 2019).

\section{SUMMARY}

The entire depositional history record of the Tatricum domain during the Jurassic can be described and interpreted in terms of the influence of various effects of tectonic activity on sedimentation, facies development and preservation of the deposits. Three main areas can be distinguished within the High-Tatric succession (Fig. 10), characterized by different occurrences and intensities of synsedimentary tectonic phenomena, particularly in the Middle Jurassic (1) the autochthonous succession of the Kominy Tylkowe Unit, (2) the parautochtonous succession of the Kominy Tylkowe Unit, and (3) the Czerwone Wierchy and Giewont units.

The record of influence of syndepositional tectonics on the sedimentary record falls into several categories (Fig. 10). One of the most prominent is the occurrence of neptunian dykes, which are present in all three areas studied, and which host deposits ranging from the Early Jurassic (probably Sinemurian or Pliensbachian) to the Bathonian. The second broad category are the various expressions of synsedimentary block tectonics, such as block tilting demonstrated by angular unconformities, evidence of submarine and subaerial erosion, and rapid lateral thickness changes. Also these symptoms are present with various intensities in all the areas studied, commencing mainly in the Bajocian and the Bathonian of the parautochtonous successions and the Czerwone Wierchy and Giewont units. The third category is the occurrence of substantial amounts of terrigenous admixture composed of clasts of local origin, indicating the proximity of elevated source areas. Such admixtures are most abundant in the Dudziniec Formation of the autochthonous succession, and in the Krupianka Formation. And finally, the fourth category comprises various symptoms of non-deposition or condensation, such as ferruginous crusts, stromatolites, cephalopod limestones, etc., particularly common in the Bathonian of the foldic units and also in the Bajocian of the parautochtonous succession.

All these manifestations of Jurassic syndepositional extensional tectonic activity in the High-Tatric succession of the Tatra Mountains correspond well to the broader picture of the evolution of the Vahic Ocean's southern margin during the Jurassic, based on compilations of regional data. The main three postulated rifting phases that took place in the Jurassic of the Western Carpathians - the Zliechov, Devin and Krasin phases (Plašienka, 2003; Froizheim et al., 2008) - can also be recognized in the material studied. Most profoundly developed are the effects of the Bajocian/Bathonian Krasin phase, which corresponds to the time of deposition of the Smolegowa and Krupianka formations, and is reflected by a whole variety of sedimentary and erosional phenomena (Fig. 10). More difficult is the recognition of the Zliechov and Devin phases (respectively Hettangian-Sinemurian and Toarcian); that is due to the imprecise internal stratigraphy of the Dudziniec Formation, but these probably can be linked to the episodes of neptunian dyke formation and/or increased input of terrigenous material into the basin.

The history outlined of the southern rim of the Vahic Ocean generally follows the same path as in the Alpine sector of the Alpine-Mediterranean Tethys. However, the exact relation between the Alpine and Carpathian Mesozoic oceanic realms is still a matter of long-lasting controversy (cf. Mahel', 1981; Froitzheim et al., 2008; Plašienka, 2012), and exact correlation is hindered by a lack of precise dating of some crucial events and phenomena. Nevertheless, notable analogues in the successions, and particularly in the positions of erosional events 
and associated stratigraphic gaps, can be found between the Central Western Carpathians and the Northern Calcareous Alps of the Austroalpine Domain (e.g., Mandl, 2000; Gawlick et al., 2009), as well as with the French Western Alps of Dauphiné (Dumont et al., 1996). Somewhat surprisingly, the closest analogue in terms of sedimentary development of the High-Tatric succession, with similar Bathonian facies with stromatolites, can be found in the Villany Mountains of southern Hungary (Radwański and Szulczewski, 1966; Géczy and Galácz, 1998).
Acknowledgements. I wish to express my gratitude to Prof. M. Szulczewski, who twenty-five years ago introduced me to the geology of the Jurassic of the High-Tatric succession. I have continued my interest in this field ever since. The authorities of the Tatra National Park are thanked for permission to conduct fieldwork and to collect samples throughout all the years of studies. The paper has greatly benefited from valuable and constructive comments of J. Grabowski, R. Jach and R. Aubrecht, who reviewed the manuscript.

\section{REFERENCES}

Andrusov, D., 1958. Geology of the Czechoslovakian Carpathians, T I (in Slovak). Slovenska Academia Vied., Bratislava.

Andrusov, D., 1959. Geology of the Czechoslovakian Carpathians, T II (in Slovak). Slovenska Academia Vied., Bratislava.

Andrusov, D., Bystrický, J., Fusán, O., 1973. Outline of the structure of the Western Carpathians. Guidebook for the geological excursion, X Congress of the Carpathian-Balkan Geological Association. Bratislava.

Aubrecht, R., Kozur, H., 1995. Pokornyopsis (Ostracoda) from submarine fissure fillings and cavities in the Late Jurassic of Czorsztyn Unit and the possible origin of the recent anchialine fauna. Neues Jahrbuch für Geologie and Paläontologie Abhandlungen, 196: 1-17.

Aubrecht, R., Schlögl, J., 2011. Jurassic submarine troglobites: is there any link to the recent submarine cave fauna? Hydrobiologia, 677: 3-14.

Bac-Moszaszwili, M., Burchart, J., Głazek, J., Iwanow, A., Jaroszewski, W., Kotański, Z., Lefeld, J., Mastella, L., Ozimkowski, W., Roniewicz, P., Skupiński, A., Westwalewicz-Mogilska, E., 1979. Geological map of the Polish Tatra Mountains 1:30 000. Wyd. Geol., Warszawa.

Bąk, M., Bąk, K., 2019. Palaeoceanographic regime during the Oxfordian-Kimmeridgian in the Western Tethys recorded by radiolarian assemblages in the siliceous sediments of the Pieniny Klippen Belt, Carpathians. Geological Journal, 54: 3362-3375.

Bernoulli, D., Jenkyns, H.C., 1974. Alpine, Mediterranean and Central Atlantic Mesozoic facies in relation to the early evolution of the Tethys. SEPM Special Publication, 19: 129-160.

Bernoulli, D., Jenkyns, H.C., 2009. Ancient oceans and continental margins of the Alpine-Mediterranean Tethys: deciphering clues from Mesozoic pelagic sediments and ophiolites. Sedimentology, 56: 149-190.

Birkenmajer, K., 1977. Jurassic and Cretaceous lithostratigraphic units in the Pieniny Klippen Belt, Carpathians, Poland. Studia Geologica Polonica, 45: 1-158.

Birkenmajer, K., 1986. Stages of structural evolution of the Pieniny Klippen Belt. Studia Geologica Polonica, 88: 7-32.

Clari, P.A., Dela Pierre, F., Martire, L., 1995. Discontinuities in carbonate successions: identification, interpretation and classification of some Italian examples. Sedimentary Geology, 100: 97-121.

Csontos, L., Vörös, A., 2004. Mesozoic plate tectonic reconstruction of the Carpathian region. Palaeogeography, Palaeoclimatology, Palaeoecology, 210: 1-56.

Decarlis, A., Beltrando, M., Manatschal, G., Ferrando, S., Carosi, R., 2017. Architecture of the distal Piedmont-Ligurian rifted margin in NW Italy: hints for a flip of the rift system polarity. Tectonics, 36: 2388-2406.

Dumont, T., Wieczorek, J., Bouillin, J.-P., 1996. Inverted Mesozoic rift structures in the Polish Western Carpathians (High-Tatric units). Comparison with similar features in the Western Alps. Eclogae Geologicae Helvetiae, 89: 181-202.
Feinst-Burkhardt, S., Götz, A.E., Szulz, J., Borkhataria, R., Geluk, M., Haas, J., Hornung, J., Jordan, P., Kempf, O., Michalík, J., Nawrocki, J., Reinhardt, L., Ricken, W., Röhling, H-G., Rüffet, T., Török, A., Zühlke, R., 2008. Triassic. In: The Geology of Central Europe, Mesozoic and Cenozoic, 2 (ed. T. McCann): 749-821. Geological Society, London.

Frisch, W., 1979. Tectonic progradation and plate tectonic evolution of the Alps. Tectonophysics, 60: 121-139.

Froitzheim, N., Plašienka, D., Schuster, R., 2008. Alpine tectonics of the Alps and Western Carpathians. In: The Geology of Central Europe, Mesozoic and Cenozoic, 2 (ed. T. McCann): 1141-1232. Geological Society, London.

Galácz, A., Matyja, B., 1999. Passendorfer's Middle Jurassic ammonites from the High Tatras. $V$ International Symposium on cephalopods - present and past, Vienna. Abstract Volume Berichte Geologische Bundesanstalt, 46: 40a.

Gawlick, H.-J., Missoni, S., Schlagintweit, F., Duzuku, H., Frosch, W., Krystyn, L., Blau, J., Lein, R., 2009. Jurassic tectonostratigraphy of the Austroalpine Domain. Journal of Alpine Geology, 50: 1-152.

Gaździcki, A., 1975. Lower Liassic (Gresten Beds) microfacies and foraminifers from the Tatra Mountains. Acta Geologica Polonica, 25: 385-398.

Gaździcki, A., 1983. Foraminifers and biostratigraphy of Upper Triassic and Lower Jurassic of the Slovakian and Polish Carpathians. Palaeontologia Polonica, 4: 109-169.

Gaździcki, A., 2014a. Skały węglanowe triasu górnego (retyk) (in Polish). In: Sedimentary Rocks of the Tatra Mountains (eds. R. Jach., T. Rychliński and A. Uchman): 141-151. Wydawnictwa Tatrzańskiego Parku Narodowego, Zakopane.

Gaździcki, A., 2014b. Skały klastyczne i węglanowe jury dolnej (formacja z Kopieńca) (in Polish). In: Sedimentary Rocks of the Tatra Mountains (eds. R. Jach., T. Rychliński and A. Uchman): 154-159. Wydawnictwa Tatrzańskiego Parku Narodowego, Zakopane.

Gaździcki, A., Iwanow, A., 1976. The diachronism of the Rhaetic and "Gresten" beds in the Tatra Mts (West Carpathians). Bulletin de l'Académie Polonaise des Sciences. Série des Sciences de la Terre, 24: 117-122.

Gaździcki, A., Michalík, J., Planderová, M., Sýkora, M., 1979. An Upper Triassic-Lower Jurassic sequence in the Križna Nappe (West Tatra Mountains, West Carpathians, Czechoslovakia). Západne Karpaty - Geológia, 5: 119-148.

Géczy, B., Galácz, A., 1998. Bathonian ammonites from the classic Middle Jurassic locality of Villany, South Hungary. Revue de Paleobiologie, 17: 479-511.

Głuchowski, E., 1986. Jurassic and Lower Cretaceous articulate crinoids of the Pieniny Klippen Belt in Poland (in Polish with English summary). Przegląd Geologiczny, 34: 304-309.

Głuchowski, E., 1987. Jurassic and Early Cretaceous articulate Crinoidea from the Pieniny Klippen Belt and the Tatra Mountains, Poland. Studia Geologica Polonica, 94: 1-102. 
Godet, A., 2013. Drowning unconformities: paleoenvironmental significance and involvement of global processes. Sedimentary Geology, 293: 45-66

Golonka, J., Krobicki, M., 2004. Jurassic paleogeography of the Pieniny and Outer Carpathian basins. Rivista Italiana di Paleontologia e Stratigrafia, 110: 5-14.

Gradziński, M., Tyszka, J., Uchman, A., Jach, R., 2004. Large microbial-foraminiferal oncoids from condensed Toarcian deposits: case study from the Tatra Mountains, Poland. Palaeogeography, Palaeoclimatology, Palaeoecology, 213: 133-151.

Grochocka-Rećko, K., 1963. Geology of Wyżnia Świstówka (Western Tatra) (in Polish with English summary). Acta Geologica Polonica, 13: 239-270.

Gruszczyński, M., 1998. Chemistry of Jurassic seas and its bearing on the existing organic life. Acta Geologica Polonica, 48: 1-29.

Horwitz, L., Rabowski, F., 1922. Sur le Lias et le Dogger hauttatriques de la Tatra (in Polish with French summary). Posiedzenia Naukowe Państwowego Instytutu Geologicznego, 3: 15-18.

Hsü, K., 1983. Neptunic dikes and their relatiojn to the hydrothermal circulation of submarine hydrothermal systems. Geology, 11: 455-457.

Ivanova, D.K., Schlögl, J., Tomašových, A., Lathuilière, B., Golej, M., 2019. Revisiting the age of Jurassic coral bioherms in the Pieniny Klippen Belt (Western Carpathians) on the basis of benthic foraminifers. Geologica Carpathica, 70: 113-134.

Iwanow, A., 1973. New data on geology of the Lower Sub-Tatric succession in the eastern part of the Tatra Mts. Bulletin de l'Académie Polonaise des Sciences, Série des Sciences de la Terre, 21: 65-74.

Iwanow, A., Wieczorek, J., 1987. Problem of the highest units in the Tatra Mts (in Polish with English summary). Przegląd Geologiczny, 35: 525-528.

Jach, R., 2002. Lower Jurassic Spiculite Series from the Križna Unit in the Western Tatra Mts, Western Carpathians, Poland. Annales Societatis Geologorum Poloniae, 72: 131-144.

Jach, R., 2005. Storm-dominated deposition of the Lower Jurassic crinoidal limestones in the Krížna Unit, Western Tatra Mountains, Poland. Facies, 50: 561-572.

Jach, R., 2007. Bositra limestones - a step towards radiolarites: case study from the Tatra Mountains. Annales Societatis Geologorum Poloniae, 77: 161-170.

Jach, R., 2014. Skały węglanowe i krzemionkowe jury dolnej i środkowej (formacja wapieni z Hucisk) (in Polish). In: Sedimentary Rocks of the Tatra Mountains (eds. R. Jach, T. Rychliński and A. Uchman): 172-180. Wydawnictwa Tatrzańskiego Parku Narodowego, Zakopane.

Jach, R., Dudek, T., 2005. Origin of a Toarcian manganese carbonate/silicate deposits from the Krížna Unit, Tatra Mountains, Poland. Chemical Geology, 224: 136-152.

Jach, R., Reháková, D., 2019. Middle to Late Jurassic carbonate-biosiliceous sedimentation and palaeoenvironment in the Tethyan Fatricum domain, Krížna nappe, Tatra Mts. Western Carpathians. Annales Societatis Geologorum Poloniae, 89: $1-46$.

Jach, R., Uchman, A., 2014. Skały węglanowe i krzemionkowe jury środkowej i górnej (in Polish). In: Sedimentary Rocks of the Tatra Mountains (eds. R. Jach, T. Rychliński and A. Uchman): 181-188. Wydawnictwa Tatrzańskiego Parku Narodowego, Zakopane.

Jach, R., Djerić, N., Goričan, Š., Reháková, D., 2014. Integrated stratigraphy of the Middle Upper Jurassic of the Krížna Nappe, Tatra Mountains. Annales Societatis Geologorum Poloniae, 84: 1-33.

Jach, R., Grabowski, J., Uchman, A., 2017. Field Trip A: Jurassic and Lower Cretaceous of the Križna Nappe in the Western Tatra Mountains. Jurassica XIII; Jurassic Geology of the Tatra Mts. Abstracts and Field Trip Guidebook; Poland Kościelisko near Zakopane, 19-23 June 2017: 75-94.
Jach, R., Reháková, D., Uchman, A., 2012. Biostratigraphy and palaeoenvironment of the Kimmeridgian-Lower Tithonian pelagic sediments of the Krížna nappe, Lejowa Valley, Tatra Mts., southern Poland. Geological Quarterly, 56 (4): 773-788.

Jaglarz, P., Gaździcki, A., Michalík, J., 2014. Skały węglanowe i klastyczne triasu górnego (retyk) (in Polish). In: Sedimentary Rocks of the Tatra Mountains (eds. R. Jach, T. Rychliński and A. Uchman): 65-74. Wydawnictwa Tatrzańskiego Parku Narodowego, Zakopane.

Jenkyns, J., 1971. Speculations on the genesis of crinoidal limestones in the Tethyan Jurassic. Geologische Rundschau, 60: 471-488.

Jezierska, A., Łuczyński, P., 2016. Jurassic unconformities in the High-Tatric succession, Tatra Mountains, Poland. Geological Quarterly, 60 (2): 273-290.

Jezierska, A., Łuczyński, P., Staśkiewicz, A., 2016. Carbonate-clastic sediments of the Dudziniec Formation in the Kościeliska Valley (High-Tatric series, Tatra Mountains, Poland): role of syndepositional tectonic activity in facies development during the Early and Middle Jurassic. Geological Quarterly, 60 (4): 869-880

Jurewicz, E., 2005. Geodynamic evolution of the Tatra Mts. and the Pieniny Klippen Belt (Western Carpathians): problems and comments. Acta Geologica Polonica, 55: 295-338.

Jurewicz, E., 2012. Nappe-thrusting processes in the Tatra Mountains (in Polish with English summary). Przegląd Geologiczny, 60: 432-451.

Kasting, J., Howard, T., Wallman, K., Veizer, J., Shields, J., 2006. Paleoclimates, ocean depth, and the oxygen isotopic composition of seawater. Earth and Planetary Science Letters, 252: $82-93$

Kostiukow, J., 1963. Geological picture of Wielka Świstówka, Kocioł Mułowy and Kocioł Litworowy (in Polish with English summary). Acta Geologica Polonica, 13: 223-238.

Kotański, Z., 1959a. Stratigraphic sections of the High-Tatric series in the Polish Tatra Mts (in Polish with English summary). Biuletyn Instytutu Geologicznego, 139: 1-160.

Kotański, Z., 1959b. Stratigraphy, sedimentology and palaeogeography of the High-Tatric Triassic in the Tatra Mountains. Acta Geologica Polonica, 9: 113-145.

Kotański, Z., 1961. Tectogénèse et reconstitution de la paléogeographie de la zone hauttatrique dans les Tatra (in Polish with French summary). Acta Geologica Polonica, 11: 187-413.

Kotański, Z., 1973. Upper and Middle Sub-Tatric Nappe in the Tatra Mts. Bulletin de l'Académie Polonaise des Sciences, Série des Sciences de la Terre, 21: 75-83.

Kotański, Z., 1979. The position of the Tatra Mts. in the Western Carpathians (in Polish with English summary). Przegląd Geologiczny 27: 359-368.

Kozur, H., Mock, R., 1997. New paleogeographic and tectonic interpretations in the Slovakian Carpathians and their implications for correlations with the Eastern Alps and other parts of the western Tethys. Part II: Inner Western Carpathians. Mineralia Slovaca, 29: 164-209.

Krobicki, M., Wierzbowski, A., 2004. Stratigraphic position of the Bajocian crinoidal limestones and their palaeogeographic significance in evolution of the Pieniny Klippen Basin. Tomy Jurajskie, 2: 69-82.

Krobicki, M., 2019. Bajocian and Tithonian/Berriasian tectonic reorganizations in the northernmost part of the Western Tethys (Pieniny Klippen Belt case study) - palaeoenvironmental and palaeoceanographic repercussions. XIVth Jurassica Conferrence Field Trip Guide and Abstracts Book, Bratislava: 131-132.

Lefeld, J., 1957. Geological structure of Zawrat Kasprowy and Kopa Magury (in Polish with English summary). Acta Geologica Polonica, 7: 281-302

Lefeld, J., Gaździcki, A., Iwanow, A., Krajewski, K., Wójcik, K., 1985. Jurassic and Cretaceous lithostratigraphic units of the Tatra Mountains. Studia Geologica Polonica, 84: 1-93. 
Lehner, B., 1991. Neptunian dykes along a drowned carbonate platform margin: an indication of recurrent extensional tectonic activity? Terra Nova, 3: 593-602.

Lemoine, M., Bas, T., Arnaud-Vanneau, A., Arnaud, H., Dumont, T., Gidon, M., Bourbon, M., Graciansky, P.C., Rudkiewicz, J.L., Megard-Galli, J., Tricart, P., 1986. The continental margin of the Mesozoic Tethys in the Western Alps. Marine and Petroleum Geology, 3: 179-199.

Lewandowski, M., Krobicki, M., Matyja, B.A., Wierzbowski, A., 2005. Palaeogeographic evolution of the Pieniny Klippen Basin using stratigraphic and palaeomagnetic data from the Veliky Kamenets section (Carpathians, Ukraine). Palaeogeography, Palaeoclimatology, Palaeoecology, 216: 53-72.

Łuczyński, P., 1999. Sedymentacja środkowej jury w jednostkach wierchowych Tatr (in Polish). Unpublished Ph.D. thesis, University of Warsaw.

Łuczyński, P., 2000. Zasadność zastosowania jednostek litostratygraficznych pochodzących z Pienińskiego Pasa Skałkowego w podziale tatrzańskim na podstawie grupy Dunajca (in Polish). Polska Grupa Robocza Systemu Jurajskiego, I spotkanie - Wiktorowo 28-29 wrzesień 2000, Abstract Book: 17.

Łuczyński, P., 2001a. Development history of Middle Jurassic neptunian dykes in the High-Tatric series, Tatra Mountains, Poland. Acta Geologica Polonica, 51: 237-252.

Łuczyński, P., 2001b. Pressure-solution and chemical compaction of condensed Middle Jurassic deposits, High-Tatric series, Tatra Mountains. Geologica Carpathica, 52: 91-102.

Łuczyński, P., 2002. Depositional evolution of the Middle Jurassic carbonate sediments in the High-Tatric succession, Tatra Mountains, Western Carpathians, Poland. Acta Geologica Polonica, 52: 365-378.

Łuczyński, P., 2014a. Skały węglanowe jury środkowej (in Polish). In: Sedimentary Rocks of the Tatra Mountains (eds. R. Jach., T. Rychliński and A. Uchman): 82-89. Wydawnictwa Tatrzańskiego Parku Narodowego, Zakopane.

Łuczyński, P., 2014b. Skały węglanowe jury górnej (in Polish). In: Sedimentary Rocks of the Tatra Mountains (eds. R. Jach., T. Rychliński and A. Uchman): 90-96. Wydawnictwa Tatrzańskiego Parku Narodowego, Zakopane.

Łuczyński, P., Jezierska, A., 2017. Field Trip D: Jurassic of the High-Tatric succession, Western Tatra Mts: Dolina Kościeliska and Dolina Miętusia Valleys, Wielka Świstówka. Jurassica XIII; Jurassic Geology of the Tatra Mts. Abstracts and Field Trip Guidebook; Poland Kościelisko near Zakopane, 19-23 June 2017: 118-128.

Łuczyński, P., Jezierska, A., 2018. Neptunian dykes penetrating the Lower Jurassic Dudziniec Formation in the autochthonous High-Tatric succession, Tatra Mountains, Western Carpathians, Poland. Acta Geologica Polonica, 68: 555-570.

Mahel', M., 1981. Island character of Klippen Belt: Vahicum continuation of Southern Penninicum in West Carpathians. Geologicky Zbornik - Geologica Carpathica, 32: 293-305.

MandI, G., 2000. The Alpine sector of the Tethyan shelf - examples of Triassic to Jurassic sedimentation and deformation from the Northern Calcareous Alps. Mitteilungen der Österreichischen Geologischen Gesellschaft, 92: 61-77.

Marino, M., Santantonio, M., 2010. Understanding the geological record of carbonate platform drowning across rifted Tethys margin: examples from the Lower Jurassic from Apennines and Sicily (Italy). Sedimentary Geology, 225: 116-137.

Masini, E., Manatschal, G., Mohn, G., 2013. The Alpine Tethys rifted margins: reconciling old and new ideas to understand the stratigraphic architecture of magma-poor rifted margins. Sedimentology, 60: 174-196.

Matyszkiewicz, J., Krajewski, M., Kochman, A., Kozłowski, A., Duliński, M., 2016. Oxfordian neptunian dykes with brachiopods from the southern part of the Kraków Częstochowa Upland (southern Poland) and their links to hydrothermal vents. Facies, 62: 12.

McCann, T. (ed.), 2008. The Geology of Central Europe, 2: Mesozoic and Cainozoic. Geological Society of London, London.
Michalík, J., 1980. A palaeonvironmental and palaeoecological analysis of the West Carpathian part of the northern Tethyan Nearshore region in the latest Triassic time. Rivista Italiana di Paleontologia e Stratigraphia, 85: 1047-1064.

Michalík, J., 1993. Mesozoic tensional basin in the Alpine-Carpathian shelf. Acta Geologica Hungarica, 36: 395-403.

Michalík, J., 1994. Notes on the paleogeography and paleotectonics of the Western Carpathians area during the Mesozoic. Mitteilungen der Österreichischen Geologischen Gesellschaft, 86: 101-110.

Michalík, J., Gaździcki, A., 1980. Is the Strazov nappe present in the Tatra Mts? (in Polish with English summary) Przegląd Geologiczny, 28: 616-619.

Michalík, J., Kátlovský, V., Hluštic, A., 1988. Plant remains in the Tomanova Formation (Uppermost Triassic, West Carpathians): their origin, composition and diagenetic alternation. Geologický Zbornik, Geologica Carpathica, 39: 523-537.

Michalík, J., Lintnerová, O., Gaździcki, A., Soták, J., 2007. Record of environmental changes in the Triassic/Jurassic boundary interval in the Zliechov Basin, Western Carpathians. Palaeogeography, Palaeoclimatology, Palaeoecology, 244: 71-88.

Michalík, J., Lintnerová, O., Wójcik-Tabol, P., Gaździcki, A. Grabowski, J., Golej, M., Šimo, V., Záhradníková, B., 2013. Palaeoenvironments during the Rhaetian transgression and the colonization history of marine biota in the Fatric Unit (Western Carpathians): Geologica Carpathica, 27: 299-318.

Mišík, M., 1964. Lithofazielle Studien im Lias der Grossen Fatra und im westlischen Teil der Niederen Tatra. Geologicky Zbornik, 11: 11-36.

Mišík, M., 1998. Peculiar types of thin veins in the Mesozoic carbonates and silicates of the Western Carpathians. Geologica Carpathica, 49: 271-289.

Mišík, M., Sýkora, M., Aubrecht, R., 1994. Middle Jurassic scarp breccias with clefts filled by Oxfordian and Valanginian-Hauterivian sediments, Krasin near Dolna Suča (Pieniny Klippen Belt, Slovakia). Geologica Carpathica, 45: 343-356.

O’Dogherty, L., Sandoval, J., Bartolini, A., Bruchez, S., Bill, M., Guex, J., 2006. Carbon-isotope stratigraphy and ammonite faunal turnover for the Middle Jurassic in the Southern Iberian paleomargin. Palaeogeography, Palaeoclimatology, Palaeoecology, 239: 311-333.

Oszczypko, N., Ślączka, A., Oszczypko-Clowes, M., Olszewska, B., 2015. Where was the Magura Ocean? Acta Geologica Polonica, 65: 319-344.

Passendorfer, E., 1934. Jak powstały Tatry (in Polish). Książnica Atlas, Lwów.

Passendorfer, E., 1936. Studien über die Stratigraphie and Paläontologie des Hochtatrischen Jura in Tatry I (in Polish with German summary). Annales de la Société géologique de Pologne, 11: 1-22.

Passendorfer, E., 1938. Étude sur la stratigraphie at paléontologie du Jurassique hauttatrique dans les Tatras II (in Polish with French summary). Prace Towarzystwa Przyjaciół Nauk, Wilno, 12: $165-173$

Plašienka, D., 1995. Passive and active margin history of the northern Tatricum (Western Carpathians, Slovakia). Geologische Rundshau, 84: 748-760.

Plašienka, D., 2003. Dynamics of Mesozoic pre-orogenic rifting in the Central Western Carpathians. Mitteilungen der Österreichischen Geologischen Gesellshaft, 94: 79-98.

Plašienka, D., 2012. Jurassic syn-rift and Cretaceous syn-orogenic, coarse-grained deposits related to opening and closere of the Vahic (South Penninic) Ocean in the Western Carpathians - an overview. Geological Quarterly, 56 (4): 601-628.

Plašienka, D., 2018. Continuity and episodicity in the early Alpine tectonic evolution of the Western Carpathians: how large-scale processes are expressed by the orogenic architecture and rock record data. Tectonics, 37: 2029-2079.

Plašienka, D., Soták, J., 2015. Evolution of Late Cretaceous-Palaeogene synorogenic basins in the Pieniny Klippen Belt and adjacent zones (Western Carpathians, Slovakia): tec- 
tonic controls over a growing orogenic wedge. Annales Societatis Geologorum Poloniae, 85: 43-76.

Plašienka, D., Grecula, P., Putiš, M., Kováč, M., Hovorka, D., 1997. Evolution and structure of the Western Carpathians: an overview. Mineralia Slovaka - Monograph: 67-72.

Polák, M., Ondrejičkovä, A., Wieczorek, J., 1998. Lithostratigraphy of the Ždiar Formation of the Križna Nappe (Tatra Mts.). Slovak Geological Magazine, 4: 35-52.

Popiołek, M., Salata D., Uchman, A., 2010. Petrography and provenance of Lower Jurassic sandstones of the Med'odoly Sandstone Formation in the Križna Unit of the Kopy Sołtysie region in the Tatra Mountains (in Polish with English summary). Przegląd Geologiczny, 58: 154-162.

Prokoph, A., Shields, G., Veizer, J., 2008. Compilation of time-series analysis of a marine carbonate $\delta^{18} \mathrm{O}, \delta^{13} \mathrm{C},{ }^{87} \mathrm{Sr} /{ }^{86} \mathrm{Sr}$ and $\delta^{34} \mathrm{~S}$ database through Earth history. Earth-Science Reviews, 87: 113-133.

Rabowski, F., 1954. Recherches géologiques de la région de Kominy Tylkowe dans la Tatra, exécutées en 1938 (in Polish with French summary). Biuletyn Instytutu Geologicznego, 86: 29-35.

Rabowski, F., 1959. High-Tatric series in western Tatra (in Polish with English summary). Prace Instytutu Geologicznego, 27: $1-178$.

Radwański, A., 1959a. Littoral structures (cliff, clastic dikes and veins) and borings of Potamilla in the High-Tatric Lias (in Polish with English summary). Acta Geologica Polonica, 9: 231-280.

Radwański, A., 1959b. Researches on petrography of the High-Tatric Lias (in Polish with English summary). Przegląd Geologiczny, 7: 359-362.

Radwański, A., 1968. Petrographical and sedimentological studies of the High-Tatric Rhaetic in the Tatra Mountains (in Polish with English summary). Studia Geologica Polonica, 25: 3-146.

Radwański, A., Szulczewski, M., 1966. Jurassic stromatolites of the Villany Mountains (southern Hungary). Annales Universitatis Scientiarum Budapestinensis de Rolando Eötvös Nominatae, Sectio Geologica, 9: 87-107.

Roda, M., Regorda, A., Spalla, M.I., Marotta, A.M., 2019. What drives Alpine Tethys opening? Clues from the review of geological data and model predictions. Geological Journal, 54: 2646-2664

Rychliński, T., Uchman, A., Gaździcki, A., 2018. Lower Jurassic Bahamian-type facies in the Choč Nappe (Tatra Mts, West Carpathians, Poland) influenced by paleocirculation in the Western Tethys. Facies, 64: 15.

Santantonio, M., 1994. Pelagic carbonate platforms in the geologic record: their classification and sedimentary and paleotectonic evolution. AAPG Bulletin, 78: 122-141.

Schlögl, J., Mangold, C., Tomašových, A., Golej, M., 2009. Early and Middle Calovian ammonites from the Pieniny Klippen Belt (Western Carpathians) in hiatal successions: unique biostratigraphic evidence from sediment-filled fissure deposits. Neues Jahrbuch für Geologie and Paläontologie, Abhandlungen, 252: 55-79.

Segit, T., Matyja, B., Wierzbowski, A., 2015. The Middle Jurassic succession in the central sector of the Pieniny Klippen Belt (Skrzycne Creek): implications for the timing of the Czorsztyn Ridge development. Geologica Carpathica, 66: 285-302.

Sieciarz, K., 1963. Geological structure of the eastern slopes of Kopa Kondracka (in Polish with English summary). Acta Geologica Polonica, 13: 271-293

Siemiradzki, J., 1923. Fauna utworówliasowych i jurajskich Tatr i Podhala (in Polish). Archiwum Towarzystwa Naukowego we Lwowie, 3: 15-66.

Smart, P.L., Palmer, R.J., Whitaker, F., Wright, V.P., 1987. Neptunian dykes and fissure fills: an overview and account of some modern examples. In: Paleokarst (eds. N.P. James and P.W. Choquette): 149-163. Springer-Verlag, New York.

Szulczewski, M., 1963a. The Bathonian stromatolites in the Tatra Mts (in Polish with English summary). Acta Geologica Polonica, 13: 25-145.
Szulczewski, M., 1963b. The geology of Mała Świstówka in western Tatra (in Polish with English summary). Acta Geologica Polonica, 13: 199-222.

Szulczewski, M., 1965. Observation sur la génèse des calcaires noduleux des Tatras (in Polish with French summary). Annales de la Société Geologique de Pologne, 35: 243-257.

Szulczewski, M., 1968. Jurassic stromatolites of Poland (in Polish with English summary). Acta Geologica Polonica, 18: 1-99.

Thierry, J., Barrier, E., 2000a. Map 8. Middle Toarcian. In: Atlas Peri-Tethys, Paleogeographical Maps (eds. J. Dercourt, M. Gaetani, B. Vrielynck, B. Barrier, B. Biju-Duval, M. Brunet J.P. Cadet, S. Crasquin and M. Sandulescu): CCG-MCGMW, Peri-Tethys Programme, Paris.

Thierry, J., Barrier, E., 2000b. Map 9. Middle Callovian. In: Atlas Peri-Tethys, Paleogeographical Maps (eds. J. Dercourt, M. Gaetani, B. Vrielynck, B. Barrier, B. Biju-Duval, M. Brunet J.P. Cadet, S. Crasquin and M. Sandulescu): CCG-MCGMW, Peri-Tethys Programme, Paris.

Turnau-Morawska, M., 1953. Kajper tatrzański, jego petrografia i sedymentologia (in Polish). Acta Geologica Polonica, 3: 33-102.

Turnau-Morawska, M., 1955. Remarks concerning sedimentation of the Werfen Beds in Tatra (in Polish with English summary). Rocznik Polskiego Towarzystwa Geologicznego, 23: 37-52.

Uchman, A., 1988. Red limestones - youngest member of the Choč Unit, Tatra Mts. Poland. Annales Societatis Geologorum Poloniae, 58: 267-276.

Uchman, A., 1993. Lower Jurassic carbonate sedimentation controlled by tilted blocks in the Choč Unit in the Tatra Mts., Poland. Zentralblatt für Geologie und Paläontologie: 875-883.

Uchman, A., 2014a. Sedimentary rocks of the Tatra Mountains - Introduction. In: Sedimentary Rocks of the Tatra Mountains (eds. R. Jach, T. Rychliński and A. Uchman): 23-28. Wydawnictwa Tatrzańskiego Parku Narodowego, Zakopane.

Uchman, A., 2014b. Jura płaszczowiny choczańskiej (Hronikum) (in Polish). In: Sedimentary rocks of the Tatra Mountains (eds. R. Jach, T. Rychliński and A. Uchman): 223-229. Wydawnictwa Tatrzańskiego Parku Narodowego, Zakopane.

Uchman, F., Tchoumatchenco, P., 1994. Remarks on the stratigraphy and brachiopod palaeobiogeography in the Lower Jurassic Hierlatz-Type Limestone Facies; the Choč Unit, Central Western Carpathians. Geologica Carpathica, 45: 195-202.

Uchman, A., Salata, D., Michalík, J., 2014a. Skały klastyczne jury dolnej (Formacja z Koperszadów) (in Polish). In: Sedimentary rocks of the Tatra Mountains (eds. R. Jach, T. Rychliński and A. Uchman): 160-163. Wydawnictwa Tatrzańskiego Parku Narodowego, Zakopane.

Uchman, A., Jach, R., Iwańczuk, J., 2014b. Skały węglanowe jury dolnej i środkowej (Formacja margli z Sołtysiej) (in Polish). In: Sedimentary rocks of the Tatra Mountains (eds. R. Jach, T. Rychliński and A. Uchman): 164-171. Wydawnictwa Tatrzańskiego Parku Narodowego, Zakopane.

Uhlig, V., 1897. Die Geologie des Tatra Gebirges. I. Einleitung und Stratigraphischer Theil. Denkschriften der kaiserlichen Akademie der Wissenschaften mathematisch-naturwissenschaftliche Klasse, 64: 643-684

Vozár, J., Káčer, Š., 1996. Geologická Mapa Slovenskej Republiky 1:500 000. Geologická Služba Slovenskej Republiky, Bratislava.

Wall, G., Jenkyns, H., 2004. The age, origin and tectonic significance of Mesozoic sediment-filled fissures in the Mendip Hills (SW England): implications for extension models and Jurassic sea-level curves. Geological Magazine, 141: 471-504

Wendt, J., 2017. A unique fossil record from neptunian sills: the world's most extreme example of stratigraphic condensation (Jurassic, western Sicily). Acta Geologica Polonica, 67: 163-199.

Wieczorek, J., 1983. Some remarks on „Ammonitico Rosso” facies (in Polish with English summary). Przegląd Geologiczny, 31: 247-252.

Wieczorek, J., 1988. Jurassic and Cretaceous lithostratigraphic units of the Tatra Mountains - a critical commentary (in Polish with English summary). Przegląd Geologiczny, 36: 159-164. 
Wieczorek, J., 1989. Main phases of the geological evolution of the Western Tethys - outline of problematics (in Polish with English summary). Kwartalnik Geologiczny, 33 (3/4): 401-412.

Wieczorek, J., 1995. Trace fossils from Fleckenmergel Facies (Jurassic) of the Tatra Mts. Geobios, 18: 425-431.

Wieczorek, J., 2000. Mesozoic evolution of the Tatra Mountains (Carpathians). Mitteilungen der Gesselschaft der Geologie und Bergbaustudenten in Wien, 44: 241-262.

Wieczorek, J., 2001. Condensed horizons as turning events in passive margin evolution: the Tatra Mts. Examples. Zentralblatt für Geologie und Paläontologie, Teil I, Geologie, (1/2): 199-209.

Wierzbowski, A., Jaworska, M., Krobicki, M., 1999. Jurassic (Upper Bajocian-lowest Oxfordian) ammonitico rosso facies in the Pieniny Klippen Belt, Carpathians, Poland: its fauna, age, microfacies and sedimentary environment. Studia Geologica Polonica, 115: 7-74.

Winterer, E., Sarti, M., 1994. Neptunian dykes and associated features in southern Spain: mechanics of formation and tectonic implications. Sedimentology, 41: 1109-1132.

Winterer, E., Metzler, C., Sarti, M., 1991. Neptunian dykes and associated breccias (Southern Alps, Italy and Switzerland): role of gravity sliding in open and closed systems. Sedimentology, $\mathbf{3 8}$ 381-404.

Wójcik, K., 1981. Facies development of the High-Tatric Lias in the vicinity of the Chochołowska Valley (in Polish with English summary). Przegląd Geologiczny, 29: 405-410.

Wójcik, Z., 1959. High-Tatric series of the southern slopes of Bobrowiec (in Polish with English summary). Acta Geologica Polonica, 9: 165-201. 